\title{
Escravos do Atlântico equatorial: tráfico negreiro para o Estado do Maranhão e Pará (século XVII e início do século XVIIII)
}

Rafael Chambouleyron

UFPA

\section{RESUMO}

Este artigo analisa as características peculiares do tráfico negreiro para a Amazônia (Estado do Maranhão) do século XVII e início do século XVIII. Para isso destaca três elementos que permitem entender a organização e o estabelecimento de uma rota escrava para o Estado do Maranhão: as epidemias, a delicada situação da Fazenda real e os problemas decorrentes do uso de trabalhadores indígenas.

Palavras-chave: Estado do Maranhão; Tráfico negreiro; Séculos XVII-XVIII.

\begin{abstract}
This article analyses the specific features of the slave trade to the Amazon region (State of Maranhão) in the seventeenth and beginning of the eighteenth centuries. In order to understand the organization and establishment of slave trade routes to the State of Maranhão, it stresses the role played by three key elements: the epidemics of smallpox, the delicate financial situation of the royal Treasury and the extensive use of Indian labour force in the region.

Keywords: State of Maranhão; Slave trade; Seventeenth and Eighteenth centuries.
\end{abstract}

Tem sido lugar comum na historiografia caracterizar a Amazônia seiscentista (e mesmo até meados do século XVIII) como uma região abandonada ao seu próprio destino, na qual os colonos sobreviviam da coleta das drogas feitas por indígenas, da caça ao índio, das lavouras de subsistência, e na qual as ordens religiosas se desenvolviam em detrimento dos moradores. ${ }^{2} \mathrm{Nes}-$ se contexto, o estudo sobre a presença africana — associada à lavoura de açúcar ou à mineração e ao tráfico sul-atlântico — tem sido relegado a um segundo plano.

Se não há dúvida de que a principal força de trabalho no antigo Estado do Maranhão e Pará do século XVII foi a indígena, livre ou escrava, no entanto, a presença africana na região não pode ser desconsiderada. Para Anaí- 
za Vergolino-Henry e Napoleão Figueiredo foram três os pressupostos desse 'abandono'. Em primeiro lugar, não se repensar a idéia de que a mão-de-obra africana teria sido inexpressiva porque o "ciclo das drogas do sertão" teria se valido exclusivamente da mão-de-obra indígena. Em segundo lugar, não se aprofundar a reflexão sobre os "diferentes empreendimentos agrários" na região, que dependiam da mão-de-obra escrava. E, finalmente, o fato de se tentar explicar a Amazônia a partir do modelo da plantation da região açucareira. Justamente como a Amazônia não teria se enquadrado nesse modelo, o negro "se tornou um elemento ausente na construção da sociedade amazônica".

Trabalhos pioneiros como os de Manuel Nunes Pereira e Arthur Cezar Ferreira Reis, embora procurem justamente suprir a 'ausência' do africano para o período colonial, insistem na idéia de que a inexpressividade do africano se explica pela própria inconsistência dos empreendimentos agrários na região. Essa explicação se adaptaria perfeitamente ao contexto do século XVII. Para Ferreira Reis, porém, se com o decorrer da colonização a atividade agrícola se organizara, mesmo assim os moradores eram demasiado pobres para investir em escravos africanos. Seria somente com a criação da Companhia de Comércio do Grão-Pará, no ministério pombalino, que a situação mudaria de figura, até mesmo pela importância que se passava a dar à agricultura. Trabalhos posteriores, como os de Vicente Salles (cuja primeira edição é de 1971), de Colin MacLachlan e de Maria Regina Celestina de Almeida, também associaram a pouca expressividade do tráfico ao caráter incipiente dos empreendimentos agrícolas durante o século XVII. ${ }^{3}$

Embora concorde com Anaíza Vergolino-Henry e Napoleão Figueiredo, em que a plantation não pode servir de modelo para entender a presença africana no Estado do Maranhão, não há dúvida, como apontaram os diversos autores já citados, de que a experiência brasileira (isto é, do Estado do Brasil) foi insistentemente invocada pelos moradores, autoridades e até religiosos como uma opção para o 'aumento’ e 'conservação’ do Maranhão. Em inúmeros textos seiscentistas escritos do e sobre o Estado do Maranhão, a imagem de que o Estado do Brasil só havia prosperado graças ao uso de africanos torna-se um argumento fundamental para defender o urgente envio de escravos da África para a região, situação que também se projetou ao longo de todo o século XVIII, como demonstrou Dauril Alden. Um termo de vereação da Câmara de São Luís, de 1678, citado por Carlos Alberto Ximendes, por exemplo, dá conta de como os moradores argumentavam em favor do recurso ao braço indígena pela própria falta de africanos, ao deliberar que, "enquanto S.A., que Deus guarde, não resolver algum meio por onde fossemos 
abastados de Angola e Guiné", haviam requerido ao governador que "mandasse fazer tropéis aos sertões, assim para efeito de se baixarem índios forros como também alguns escravos".

O padre Antônio Vieira foi sem dúvida o representante mais ilustre dessa tese, ao advogar, como escreve António José Saraiva, uma 'acomodação' pela qual os africanos ficavam com os moradores e os jesuítas com os indígenas. Em 1661, o padre Vieira defendia que se no Maranhão eram muitos os indígenas que se escravizavam, muitos mais eram os que morriam, "como mostra a experiência de cada dia neste Estado [do Maranhão], e o mostrou no do Brasil, onde os moradores nunca tiveram remédio senão depois que se serviram com escravos de Angola. Mesma opinião tinha anos depois o vigário-geral do Maranhão, padre Domingos Antunes Tomás, segundo o qual, para o "aumento daquele Estado são necessários negros de Angola e de Guiné". Havia assim que trazer muitos escravos, "pois se sabe que o Brasil não teve aumento senão depois que nele entraram os negros de Angola e Guiné, e deixaram os escravos do gentio da terra, e o mesmo as Índias de Castela”. É que, justamente no século XVII, de acordo com Ronaldo Vainfas, se dá uma "inflexão ideológica", a partir da qual se a validade da escravidão indígena é colocada em questão, o cativeiro africano passa a ser legitimado nos discursos dos letrados coloniais. ${ }^{4}$

Entretanto, se a experiência brasileira ajuda a entender a freqüentemente invocada necessidade de escravos africanos para a região amazônica, o tráfico negreiro ao longo do século XVII e início do século XVIII se organizou a partir de pressupostos diferentes do tráfico brasileiro. Nesse sentido, para entender a constituição de uma incipiente rota escrava, torna-se fundamental considerar elementos específicos da formação da sociedade colonial no Estado do Maranhão. Neste artigo pretendo examinar três deles que me parecem centrais. Em primeiro lugar, o impacto das epidemias de varíola sobre os trabalhadores indígenas, que ensejou uma 'corrida' aos africanos, principalmente na década de 1690. Em segundo lugar, a delicada situação financeira da Fazenda real, que viu no comércio de africanos uma importante alternativa para viabilizar a reprodução do domínio militar português na região. E, em terceiro lugar, a experiência da Companhia de Comércio do Maranhão, de 1682, instituída para enviar escravos africanos ao Estado, em face de uma lei geral de liberdade indígena publicada em 1680, e cujo fim esteve determinado pela chamada "revolta de Beckman", em 1684-1685. Dois eixos caracterizaram os diversos empreendimentos para o envio de africanos ao Estado do Maranhão e Pará. Por um lado, as iniciativas partiram fundamentalmente da Corte. Diversamente de outras partes, 
a Coroa teve um papel crucial para definir, estabelecer e organizar as rotas do tráfico. Por outro lado, o tráfico negreiro para a região amazônica efetivou-se a partir de uma rota muito específica. Em vez de Atlântico sul, deveríamos falar antes de Atlântico equatorial. A ligação central aqui se fazia entre o Estado do Maranhão, a Guiné e a Mina, como veremos.

\section{“A PESTE ENTRE ESTES GENTIOS”}

Durante o século XVII, duas grandes epidemias de bexigas (varíola) irromperam nas décadas de 1660 e 1690, e representaram, como apontou David Sweet, uma "séria crise para o sistema produtivo, devastando a força de trabalho". No Estado do Maranhão, a primeira ocorreu logo após uma revolta contra os padres da Companhia de Jesus, em 1661, razão pela qual, como narra uma relação jesuítica anônima, "para que não faltasse nenhum elemento em manifestar a ira do senhor, se corrompeu o ar de tal sorte que com uma peste veemente de bexigas vai consumindo tudo. Casa houve onde, havendo vinte pessoas, só escaparam três".

São vários os relatos que se referem à epidemia de 1660. De acordo com a crônica do padre jesuíta João Felipe Bettendorf, a doença começara na casa de uma moradora do Pará, dali se espalhando para as demais capitanias do Estado. O ouvidor Maurício de Heriarte relata que, das dezoito aldeias que existiam na ilha de São Luís antes da epidemia, só haviam sobrado três. Em 1663, descrevendo as dificuldades encontradas pela missão dos padres capuchos de Santo Antônio, frei Pedro das Neves relatava a "grande mortandade que as bexigas fizeram no gentio, que é o remédio destas terras". Em junho de 1663 era a vez dos oficiais da Câmara de São Luís, que escreviam ao rei, representando o "miserável estado em que ficava esta terra e os moradores dela, sem remédio nem favor algum que V.M. fosse servido mandar a ele, e sobretudo a total ruína de mortes que têm havido nos índios, escravos e aldeias".

Já as bexigas da década de 1690 parecem ter sido ainda mais graves. Segundo o padre Bettendorf, a doença que devastaria os índios teria sido trazida por um navio que transportava escravos africanos para o Maranhão. É importante lembrar que as décadas dos surtos epidêmicos no Maranhão coincidiram com irrupções da mesma doença no Estado do Brasil e com situações de seca e fome em partes do continente africano, como mostraram Dauril Alden e Joseph Miller. Isso seguramente reforça a importância do tráfico negreiro na transmissão de algumas doenças que grassaram entre os in- 
dígenas da América portuguesa, dando margem ao estudo do que Philip Curtin chamou de "epidemiologia da migração".

O fato é que, da capitania do Maranhão, as bexigas se espalharam para as capitanias de Tapuitapera, Caeté, Pará e Cametá. De acordo com José Ribeiro do Amaral a doença teria durado cinco meses. Na capitania do Maranhão, a epidemia fora ainda agravada pela fome, causada pela seca e pelos ataques dos "índios do corso" aos moradores dos rios Mearim e Itapecuru. Em 1696, o Conselho Ultramarino relatava ao rei a grande mortandade causada pelas bexigas, que haviam matado "não só aos índios do sertão, mas também aos moradores daquelas conquistas, e aos escravos que ali estão ao serviço de seus engenhos e a cultura das suas terras". No mesmo ano, o governador Antônio de Albuquerque Coelho de Carvalho escrevia alertando que as aldeias tinham ficado "quase despovoadas com as bexigas". Em 1697, o Conselho Ultramarino insistia na amplitude da devastação, "cujo estrago não só compreendera as povoações, morrendo muitos de seus moradores e escravos, mas ainda chegara aos sertões, perecendo muita quantidade de índios”. No final do século XVII, o procurador do Estado do Maranhão concluía que o "contágio das bexigas" teria levado "entre cativos e forros o melhor de cinco mil".

Uma das reações a tanta devastação de indígenas - para além da geral reclamação sobre a miséria em que havia ficado o Estado - era o recurso a escravos vindos da África. Como já foi dito, a idéia de que o Estado do Brasil progredira graças à mão-de-obra africana era comum nas petições e documentos enviados do Maranhão. Nada mais natural, então, que em épocas de crise se recorresse ao tráfico de africanos como alternativa para a falta de trabalhadores indígenas. O irônico, no caso da década de 1690, é que a epidemia que ensejara a Coroa a incentivar o envio de africanos ao Maranhão teria justamente sido transmitida por um navio negreiro.

Em 1665, por exemplo, os oficiais da Câmara de São Luís escreviam ao Conselho Ultramarino apontando como várias vezes se haviam representado ao rei os padecimentos dos moradores do Estado do Maranhão. Para os vereadores, a causa de não prosperar o Estado era a "grande falta de escravos". Era essa "necessidade nunca satisfeita de índios, e de africanos mais tarde", da qual tão bem fala João Lúcio de Azevedo ao descrever a sociedade maranhense colonial. Os oficiais, de fato, queixavam-se de que nos últimos quatro anos tinham vindo poucos escravos do sertão, "com que se têm atenuado as fazendas de açúcares e mais lavouras". A isso se juntavam as bexigas, "peste entre estes gentios", e que haviam dizimado os índios das aldeias e matado os escravos dos moradores. Esta era a razão pela qual, alegavam, "vendo-se desen- 
ganados e obrigados da necessidade, contrataram com mercadores do reino para lhes mandarem [vir] tapanhunos de Angola e Guiné, para de todo não se perderem as fazendas". Os oficiais haviam tido aviso certo de que mercadores queriam mandar africanos ao Estado do Maranhão, para o qual os comerciantes solicitavam liberdades de direitos na carga dos navios, "pois se antepunham a grandes [perdas] e riscos de suas fazendas, pela costa ser trabalhosa”. Assim, os vereadores de São Luís pediam ao rei que concedesse tais liberdades, pagando somente meios direitos sobre a carga. Além do mais, requeriam que os tais negociantes não fossem impedidos de navegar para o Estado. Recebida a petição da Câmara de São Luís, o Conselho Ultramarino a enviava ao procurador da Fazenda, a quem parecia que, de fato, "tem mostrado a experiência que as fazendas do Maranhão se não podem [bem] [fabricar] com os índios cristãos que há nas aldeias do Estado, nem com os gentios que se conduzem dos sertões". Assim, sugeria que os comerciantes pagassem meios direitos, durante seis anos, "só no Estado do Maranhão", já que "esta perda é pouca e a utilidade que pela cultura podem ter os dízimos pode vir a ser muita”. Em sua consulta, o Conselho se conformava com o parecer do procurador, insistindo em que se deferisse a petição da Câmara, "para terem quem lhes cultive as terras, com que se aumentará aquele Estado e crescerão as rendas reais, o que se não poderá fazer sem os ditos escravos".

Uma situação semelhante se conformou na década de 1690. Entretanto, mais do que na década de 1660, de 1695 em diante, para além da solução da importação africana - que veremos em seguida —, outras alternativas foram aventadas para resolver o grave problema da escassez de força de trabalho. De fato, a falta de mão-de-obra indígena, aliada às discussões em torno da administração particular de índios, em São Paulo, seguramente influenciaram a adoção de outras opções para resolver o problema da força de trabalho. Com efeito, não só a prática de autorizar a distribuição de índios livres a moradores e a escravização de indígenas do sertão se tornou mais freqüente (embora já vigente desde 1688), mas também os descimentos privados aprovados pela Coroa (desde 1684) se tornaram mais comuns. Conseqüência da grave crise de mão-de-obra de meados da década de 1690, foram freqüentes os pedidos e a concessão de descimentos de índios, até mesmo já entrado o século XVIII. ${ }^{8}$

Ao lado dessas alternativas mais 'locais', em vários momentos foi aventada a importação de escravos africanos como uma solução para a falta de mãode-obra indígena causada pelas bexigas de 1695-1696. Na consulta em que advertira sobre a magnitude da devastação, o próprio Conselho Ultramarino 
já sugeria que se acorresse aos moradores do Maranhão com um provimento de africanos, "porque de outra maneira não só não terão com que possam acudir ao trabalho dos engenhos e a cultura dos seus frutos, mas se lhes seguirá um grande prejuízo no comércio de que vivem". Um ano mais tarde, novamente os conselheiros insistiam que se repetisse o provimento de negros, que "se tinha praticado nestes anos próximos passados", agora com uma causa "urgentíssima". Poucos dias depois, o rei escrevia ao governador informando que em razão das mortes causadas pelas bexigas havia resolvido acudir "assim com provimento de negros como com algum socorro de infantaria”. Em 1698, o Conselho Ultramarino informava que, em função da grande mortandade de índios e dos próprios escravos que haviam se enviado nos anos anteriores, seria conveniente que se continuasse com o provimento de africanos, "porque por este meio não só se lhe seguiria o interesse de terem quem os servisse e trabalhasse na cultura de seus frutos, mas em conseqüência para a Fazenda de V.M., porque sendo muitos em abundância, seria muito diferente o rendimento dos contratos".

\section{FAZENDAS E NEGROS}

O navio negreiro da década de 1690, de que fala o padre Bettendorf, e que teria levado a varíola ao Estado do Maranhão, fora seguramente enviado pela Coroa, no interior de uma dupla política de financiamento da Fazenda real no Estado e de incentivo à agricultura. Em 1691, dom Pedro II enviou uma carta ao governador do Maranhão explicando-lhe que mandara uma série de gêneros que pareciam ter "valia" no Estado, para que do procedido da venda deles se acudisse à construção das fortalezas e conserto das armas. $\mathrm{O}$ capital obtido com a venda dos gêneros não podia ter outra aplicação que não as fortificações. Advertia também ao governador que tivesse cuidado em vender os produtos "por preços em que a Fazenda real tenha aquelas ganâncias que convém”. Numa região de fronteira como o Estado do Maranhão, a insistência na conservação das fortalezas era fundamental. De fato, desde finais do século XVI, a Amazônia fora objeto do interesse de holandeses, ingleses e franceses, que se estabeleceram em várias áreas do imenso território amazônico. A conquista de boa parte do território ocidental pelos portugueses (à época da união das duas Coroas) não afastou a constante ameaça representada pela presença de outras nações européias, incluindo também a própria coroa de Castela. Porém, as fortificações eram fundamentais para a defesa do 
que poderíamos chamar de 'fronteira interna', principalmente no Cabo do Norte e na banda oriental do Maranhão, regiões continuamente assoladas pelos chamados "gentios do corso".

Em julho de 1692, diante da proposta do rei, o governador Antônio de Albuquerque Coelho de Carvalho respondia a ele relatando como havia sido feita a venda dos gêneros. Segundo as contas do governador, as fazendas haviam rendido mais de 40 mil cruzados, excetuando-se as munições para fornecimento do Estado. Entretanto, parecia a Antônio de Albuquerque Coelho de Carvalho que os bens que a Fazenda real pretendia enviar ao Estado, para gerar renda para as fortalezas, "viesse[m] antes em negros, que em outros gêneros, porque sendo aqueles o total remédio para o seu aumento, fica sendo prejuízo de menos conseqüência o faltar aos moradores alguma coisa de que não necessitam tanto, como os negros que para as lavouras e culturas importam tudo". Os escravos seguramente se venderiam no Estado, pela "reputação que têm", argumentava, podendo a venda ser feita "suavemente". Desta forma, a Fazenda real poderia gastar o dinheiro recebido aos poucos, ficando o "povo satisfeito, o Estado com alguma melhora e a Fazenda real com os interesses que se lhe procuram".

Recebida a carta do governador, em consulta do Conselho Ultramarino de novembro de 1692, foi ouvido o procurador da Fazenda, a quem não parecia conveniente que os africanos fossem embarcados por conta da Fazenda real, "porque só indo com eles seu dono davam utilidade". Sugeria, em vez disso, que se contratasse com mercadores para que os escravos, pagos em Lisboa com o dinheiro "que V.M. tinha aplicado para fornecimento do Maranhão", fossem vendidos no Maranhão por um valor pelo qual "a Fazenda real tivesse maior avanço ou igual ao dos gêneros remetidos e os moradores sem vexação tenham com que poder beneficiar suas fazendas convenientemente". O Conselho Ultramarino, conformando-se com o parecer do procurador da Fazenda, sugeria que o contrato fosse feito com a Companhia de Cabo Verde e Cacheu, ou Cacheu e Cabo Verde, criada em 1690 (e extinta em 1706), segundo António Carreira. A resolução real determinava que os escravos se vendessem a 55 mil réis, "por peça”. Um mês depois, o Conselho Ultramarino novamente fazia uma consulta sobre o assunto, dando conta ao soberano sobre os ajustes que finalmente haviam sido feitos com a Companhia de Cabo Verde.

Não há muita informação sobre o capital que financiaria o tráfico. Somente em 1691 e em 1696 há referências a esse respeito, a partir de uma determinação do rei que ordenava à Mesa da Consciência e Ordens que emprestasse ao Conselho Ultramarino o dinheiro necessário, do depósito das 
comendas da Casa de Aveiro (30 e 20 mil cruzados, respectivamente). De qualquer modo, não há dúvida, o financiamento de toda a operação seria feito pela própria Coroa, por meio do Conselho Ultramarino.

Em dezembro de 1692, fazia-se o primeiro assento com a Companhia de Cabo Verde e Cacheu, que se obrigava a entregar 145 escravos no Maranhão, a metade em "peças cotadas como é estilo irem nas carregações que se fazem na ilha Cabo Verde para o Brasil e Índias". A outra metade "de segundo lote tendo moleques e molecas, não entrando nas ditas quantias negro nem negra velhos". Estipulavam-se ainda algumas condições quanto ao cumprimento do contrato e à obrigatoriedade da Companhia de enviar os escravos ainda no ano de 1693. No mesmo mês, o rei escrevia ao governador, relatando as medidas que haviam sido tomadas, explicitando a "maior conveniência" que teriam os moradores se "em lugar das fazendas se introduzissem negros para o serviço de suas roças e lavouras". O soberano lembrava ainda que o procedido da venda dos africanos se devia aplicar no mesmo que antes se aplicava o dinheiro das fazendas.

Em janeiro de 1693, pouco tempo antes de se efetivar o envio da primeira remessa de africanos, o Conselho Ultramarino novamente apreciava o assunto. Desta vez examinara-se também um papel de João de Moura, que defendia o estabelecimento do assento com particulares em razão de a Fazenda real estar em situação delicada. Para João de Moura, o pagamento dos escravos seria feito do modo que fosse melhor aos moradores e "dos frutos que cultivarem". Ouvidos os procuradores da Fazenda e da Coroa, mais uma vez, o Conselho Ultramarino concluía que "por este meio se acudirá ao que respeita as fábricas dos gêneros, e tudo o mais que produz aquela conquista”. ${ }^{10}$

O navio Nossa Senhora da Conceição e São João Batista, que levaria os escravos ao Maranhão, ao que parece, saiu nos primeiros meses de 1693. O mestre da embarcação, Manuel Luís de Macedo, conseguiu provisão de "preferência” em março do mesmo ano. Além da provisão, o rei escrevia ao governador lembrando que favorecesse o navio. Usadas em várias partes do império, as preferências, que, para Roquinaldo Amaral Ferreira, constituíam "mecanismos pré-capitalistas que significativamente diminuíam o avanço do comércio", serviram no Estado do Maranhão para incentivar capitães e donos de navio a viajar para o Estado, dado o pequeno número de navios que aportava na região. O fato é que o patacho chegara ao Maranhão, provavelmente em maio. Desembarcaram em São Luís 139 escravos, dos quais 101 "se repartiram pelos senhores de engenho e lavradores" - gerando uma renda de mais de 16 contos de réis —, e 38 foram vendidos na praça — gerando uma recei- 
ta de mais de 6 contos de réis - , de acordo com um recenseamento das receitas e despesas do almoxarifado do Maranhão, feito em 1696.

Numa carta escrita em junho de 1693, o próprio governador informava ao Conselho Ultramarino que resolvera deixar todos os escravos na capitania do Maranhão, "repartindo-os em primeiro lugar com os senhores de engenhos, lavradores de canas e cultores do anil", tanto por requerimento da Câmara, como por lhe parecer que os moradores do Maranhão precisavam mais dos negros que os do Pará. Além do mais, insistia no seu argumento que, embora a Fazenda real ganhasse mais com a venda de gêneros, mesmo apesar do alto preço dos escravos, era fundamental pensar nos aumentos que da venda dos africanos decorriam, como o crescimento dos dízimos, o aumento do açúcar dos engenhos e o próprio incremento do comércio. Essa percepção de que o uso de africanos serviria para estimular as atividades agrícolas - seguramente decorrência do 'sucesso' do modelo 'brasileiro' - fora claramente incorporada pela Coroa. Em 1702, por exemplo, em razão dos altos preços pelos quais tinham sido vendidos os escravos, o rei escrevia uma carta ao provedor da Fazenda do Maranhão, na qual louvava o bem que tinha agido, quanto ao aumento das rendas para a Fazenda real. Entretanto, lembrava também que o provedor tinha que ter em mente "que não é o meu cuidado somente no interesse que à minha Fazenda redunda do excesso dos preços destas peças, mas juntamente do que terá com o crescimento dos dízimos, procedidos da lavoura das canas e fábrica dos engenhos e igualmente do cômodo e utilidade desses vassalos". ${ }^{11}$

Como veremos adiante, vários outros assentos foram feitos, não só com a Companhia de Cabo Verde e Cacheu, mas também com outros comerciantes. Embora a solução de a Coroa consolidar o tráfico por meio de assentos com comerciantes privados parecesse ideal tanto para a Fazenda real - que teria agora rendas para financiar as fortalezas - como para os moradores, que passariam a ter mão-de-obra escrava africana - tão esperada e desejada —, inúmeros problemas se interpuseram ao sucesso da empresa. Os principais obstáculos eram o preço dos escravos e o estado das contas e da aplicação do dinheiro obtido com o tráfico. ${ }^{12}$

Já em junho de 1693, os oficiais da Câmara de São Luís requeriam ao rei que se continuasse o provimento de negros, mas "com a moderação mais possível nos preços do que agora se observou”. Segundo o Conselho Ultramarino, entretanto, analisando essa carta em novembro de 1693, os vereadores não tinham razão para se queixar do preço dos escravos, "por ser este o ordinário por que se compram aos particulares" que lá os levam "e maiormente quan- 
do V.M. em benefício seu interessa menos nesta introdução dos escravos do que nos gêneros que lá meteu”. Assim, em dezembro do mesmo ano, o rei escrevia aos oficiais, insistindo no mesmo argumento que havia levantado o seu Conselho. Em dezembro de 1695, o rei novamente lembrava aos moradores que não tinham por que queixar-se do preço dos escravos. Em janeiro e novembro de 1697, cartas semelhantes eram enviadas aos oficiais da Câmara de Belém. Em 1702, era a vez de a Câmara de Icatu, na capitania do Maranhão, queixar-se do preço excessivo dos escravos que haviam vindo no assento (de 1702). Em carta aos oficiais da Câmara, o rei advertia que era impossível alterar-se o preço, até mesmo pela própria "carestia em que estão em todas as partes onde os vão comprar os assentistas". ${ }^{13}$

Problema igualmente delicado era o da aplicação do dinheiro que provinha da venda dos africanos (e das fazendas que também se enviavam). Foram contínuas as cartas mandadas pelo rei ao governador e aos provedores da Fazenda insistindo para que se tirasse a conta do que se obtivera e do que se gastara. Em 1700, o rei lembrava ao provedor da Fazenda do Estado que o dinheiro "se há de aplicar à fábrica e reparos das fortificações e para suprir o pagamento dos cabos e soldados, onde não chegar a Fazenda real desse Estado". A partir de meados da década de 1690, fizeram-se vários recenseamentos dos almoxarifados das capitanias do Pará e do Maranhão, com o objetivo de verificar-se, entre outras questões, a correta aplicação do dinheiro que provinha da venda de fazendas e escravos, central para as finanças da Coroa no Estado do Maranhão. A existência de livros de receita e despesas separados para as fortalezas revela a importância das rendas geradas pela vendas feitas à custa da Coroa para financiar o aparelhamento militar (embora pudesse se tratar de uma prática comum no conjunto do Império).

Em julho de 1695, por exemplo, o escrivão da Fazenda real da capitania do Pará, Clemente Soeiro Palheta, informava à Corte que a receita do almoxarifado (onde se cobravam os direitos reais) havia atingido mais de 13 contos de réis, em dois anos; já a receita do "livro das fortificações" dera mais de 21 contos de réis. Recenseamento feito no almoxarifado de São Luís, entre 1693 e 1696, indicava que a receita das fazendas enviadas pela Coroa havia sido de mais de 12 contos de réis; já a venda de 260 africanos tinha gerado mais de 41 contos de réis. Se a venda de gêneros e africanos havia gerado para a Fazenda real do Maranhão uma receita de mais de 53 contos de réis, as receitas correntes da Fazenda real na capitania do Maranhão — gerada principalmente pela cobrança dos "dízimos da terra" —, segundo o recenseamento, não haviam dado mais que 12 contos de réis (quase um quinto das rendas obtidas 
com as fazendas e negros). O dinheiro procedente da venda de fazendas e africanos, ao que parece, servia igualmente para resolver outros problemas da Coroa. Em 1696 e 1697, o rei ordenava ao Conselho Ultramarino que do dinheiro se dessem 3 mil cruzados anuais para Antônio de Albuquerque Coelho de Carvalho, "enquanto for governador, para um negócio de meu serviço de que não há de dar conta". ${ }^{14}$

Não se trata aqui de analisar as contas dos almoxarifes, para as quais, por sinal, faltam séries sistemáticas, com pouquíssimas exceções. O que se quer é revelar a importância que o incipiente tráfico negreiro (e do comércio das fazendas) havia adquirido para a frágil situação financeira da Coroa no Estado do Maranhão. Diante desse quadro, não há dúvida de que o recurso aos assentos de escravos foi uma alternativa importante, consolidada no final do século XVII e início do século XVIII.

\section{OS “MEIOS MAIS CONVENIENTES” PARA A CONSERVAÇÃO E COMÉRCIO DO MARANHÃO}

A importação de escravos africanos para o Estado do Maranhão, durante o século XVII, fora igualmente pensada a partir de um outro quadro muito específico, relacionado com os problemas decorrentes do uso de trabalhadores indígenas no Estado do Maranhão. De fato, em 1680, o príncipe regente publicava uma lei de liberdade geral dos índios, determinando, até mesmo, que os indígenas tomados em guerra justa, ofensiva ou defensiva, fossem considerados prisioneiros, "como ficam as pessoas que se tomam nas guerras da Europa”. Não cabe aqui fazer uma discussão aprofundada dessa legislação e das discussões que sua formulação suscitou. Ela se originou de "uma grande junta sobre o remédio espiritual e temporal do Maranhão", nas palavras do padre Antônio Vieira, convocada por dom Pedro II, da qual fizeram parte o secretário de Estado, o duque de Cadaval e o conde de Vale de Reis (presidente do Conselho Ultramarino), Francisco Malheiro (conselheiro do Conselho Ultramarino), o procurador da Coroa, o procurador da Fazenda, o bispo deão da Capela, o padre jesuíta Manuel Fernandes, Manuel Rodrigues Leitão e o próprio padre Vieira. "Último triunfo de Vieira na legislação indigenista", segundo Mathias Kiemen, a lei de 1680 inseria-se num conjunto de medidas que reestruturavam as formas de obtenção e uso da mão-de-obra indígena. Uma delas, integrada com a lei de liberdade, determinava que, para que os moradores tivessem quem trabalhasse "a cultura de suas searas e novas drogas que 
se têm descoberto", se importassem africanos bem como se promovesse o descimento de índios livres do sertão e sua repartição (os índios livres ficariam a cargo exclusivo dos jesuítas). Assim, de acordo com dom Felipe Condurú Pacheco, procurava-se "suprir a falta dos braços dos índios libertos".

Novamente, a solução dos problemas de mão-de-obra no Estado do Maranhão era pensada recorrendo-se aos africanos, "panacéia em todos os tempos aplicada no Brasil aos males dos colonos", como escreve João Lúcio de Azevedo. Antes mesmo da publicação das leis de liberdade e de repartição dos índios livres, em março de 1680, o príncipe autorizava o Conselho Ultramarino a tomar dinheiro “à razão de juro" para que o comerciante Pedralves Caldas pudesse introduzir africanos no Estado do Maranhão. Claramente o rei se antecipava às conseqüências que as leis de 1680 causariam no Maranhão, procurando organizar o envio de africanos — previsto numa delas — antes mesmo que as notícias chegassem ao Maranhão. Apenas um dia depois da publicação da lei de liberdade, o Conselho Ultramarino fazia uma consulta ao príncipe informando que embora não houvesse quem quisesse enviar africanos ao Maranhão, fizera uma reunião com Pedralves Caldas, persuadindo-o a tomar o negócio, a 56 mil réis por peça. Ao que parece, na verdade, o comerciante já havia sido contatado pela Coroa antes da consulta do Conselho. De qualquer modo, o fato é que a Coroa se organizara para garantir o suprimento de mão-de-obra africana para o Maranhão, num momento em que não só os escravos indígenas escasseariam, mas as novas disposições encontrariam uma forte oposição por parte dos moradores do Estado. Ao que parece, o assento com Pedralves Caldas fracassara. Já em julho de 1680, dom Pedro II encomendava novamente ao Conselho que ajustasse logo com Manuel Preto Valdez o envio de quinhentas a seiscentas peças da Guiné (desta vez a 48 mil réis cada), “com as condições que lhe parecerem justas e possíveis”. Não há mais informações sobre esse assento. ${ }^{15}$

Logo a seguir, em outubro do mesmo ano, a Coroa assentava com José Ardevicus o envio de seiscentos escravos (pagos em Lisboa a 43 mil réis), só que desta vez oriundos de Angola. Os termos do assento detalhavam a origem do capital que financiaria o traslado, a forma de recepção dos africanos no Estado do Maranhão, e estipulava que se lhe desse preferência em Angola. Em consulta ao príncipe, o Conselho Ultramarino entendia que parecera ao soberano que "o meio mais conveniente de aumentar e conservar o Estado do Maranhão era meterem-se negros". O Conselho entendia que os escravos deveriam ser pagos pelos moradores em três anos, dando primeiramente a quarta parte do valor. O preço pago por cada peça pelos moradores seria de $80 \mathrm{mil}$ 
réis, "conforme avaliação que trouxeram de Angola". Entretanto, apesar de toda a disposição da Coroa, este assento também fracassara. Ao que parece, em 1681, se é que se trata do mesmo navio, um contratador de Angola embargara a carga, para a qual se havia conseguido isenção parcial dos direitos. As coisas andaram ainda pior para o assentista, pois quase dois anos depois do envio do navio, José Ardevicus escrevia à Corte que, tendo a nau Jerusalém chegado a Angola, com preferência para sair do porto em quatro meses, alegando que o negócio estava suspenso e que também "não havia resgates", ficara incapacitado de cumprir as disposições do contrato, negando-se-lhe a licença de saída ao navio. Requeria que se lhe concedesse preferência para poder sair do porto de Luanda, dado o prejuízo que tivera com tantos anos de demora. O caso de Ardevicus revela, segundo Roquinaldo Amaral Ferreira, como "comerciantes privados eram seriamente afetados pela forma como os governadores aproveitavam-se de sua posição institucional em Luanda para manipular regulações de comércio". Ainda em 1687, Ardevicus estava às voltas com o pagamento de seus prejuízos. ${ }^{16}$

Todas estas dificuldades levaram a Coroa a contratar com um grupo de mercadores portugueses, que formaram uma companhia de comércio cujo objetivo era, entre outros, a entrega de africanos no Maranhão. Não era a primeira vez que a Coroa tentava a implantação de um monopólio de comércio. Já na década de 1670, o príncipe instaurara o "estanco dos quatro gêneros", monopólio de aço, facas, ferro e avelórios que permitiria pagar as contas da Fazenda real no Estado. Aceito em Belém, mas rejeitado em São Luís, esse primeiro estanco teve pouca duração, muito embora o soberano não aceitasse de início as reclamações dos moradores. Entretanto, até mesmo os conselheiros do Ultramarino, além do procurador da Fazenda e do procurador da Coroa, concluíam que o povo de São Luís tinha direito a rejeitar o monopólio. No fim, a própria Coroa ordenou que se reavaliasse o estanco e se procurassem alternativas para fazer frente aos gastos da Fazenda real no Estado. Segundo César Augusto Marques, fora justamente o fracasso desse primeiro monopólio que levara a Coroa a contratar com uma companhia de mercadores. Há que se lembrar, igualmente, que a experiência das companhias de comércio não era nova, nem no Império, nem muito menos na América portuguesa, com a instauração da Companhia de Comércio do Brasil.

No caso da Companhia de Comércio do Maranhão, não fica claro se a iniciativa partira realmente da Coroa ou de alguns dos mercadores que depois formariam a Companhia. Claramente, Lisboa tinha interesse em instituir uma rota regular de escravos africanos em razão das leis de liberdade, ra- 
zão pela qual tinha no início tentado contratar individualmente com Pedralves Caldas, Manuel Preto Valdez e José Ardevicus, como vimos. A existência de uma proposta para envio de africanos ao Maranhão, infelizmente sem data, assinada por um dos futuros contratadores, Pascual Pereira Jansen, revela a intenção de se enviarem apenas mil escravos, ao longo de cinco anos, "por conta da Fazenda de V.A.”. O preço pago por escravo posto no Maranhão seria de 46 mil réis, "assim pelos machos como pelas fêmeas". Esta proposta foi examinada por Bartolomeu Galvão da Rocha, que se referia ao fracasso do estanco anterior dos "quatro gêneros". Galvão da Rocha advertia o príncipe para o excesso do valor pago pelos escravos, e comentava os demais pontos da proposta. Insistia, no final, que "nunca convém a S.A., nem ao aumento daquele Estado que os negros que forem para o dito Estado se entreguem a ministro algum pelos desencaminhos que farão, e a experiência o tem mostrado". Cabia, assim, encarregar o negócio a um "homem particular". Esta parece ter sido a iniciativa inicial a partir da qual se estabeleceu depois o contrato de $1682 .{ }^{17}$

De qualquer modo, em janeiro de 1682 o príncipe ordenava ao Conselho Ultramarino que passasse alvará de confirmação do assento feito com vários comerciantes, "para a conservação do comércio do Estado do Maranhão, em utilidade de seus moradores". Pelo "assento do estanco do Maranhão e Pará, juntamente com o contrato de Cacheu", os assentistas - Manuel Preto Valdez, Pedralves Caldas, Antônio da Gama, Pascual Pereira Jansen, Antônio Rodrigues Marques e Luís Correia da Paz — obrigavam-se a introduzir 10 mil negros no Maranhão, "se tantos forem necessários para aqueles moradores fazerem suas fábricas e lavouras" à razão de quinhentos por ano. Obrigavamse igualmente a despachar ao Estado fazendas e gêneros necessários para o uso e lavouras dos portugueses, além de enviar pessoas expertas em cacau, baunilha e demais drogas para que estas fossem descobertas e cultivadas.

Quanto ao transporte dos escravos, além de se comprometer a enviar os africanos prometidos por Ardevicus, o assento estipulava a preferência que teriam as naus dos contratistas sobre qualquer outro navio, se fossem buscar peças a Angola. Ao mesmo tempo, a cláusula 27 determinava que,

para conseguir com maior facilidade a condução dos negros ao dito Estado do Maranhão ser necessário esperar os contrários e ... que ordinariamente impossibilitam fazerem-se do reino de Angola, como a experiência tem mostrado, desde logo tomam por sua conta os ditos assentistas o assento da Companhia de Cacheu, que com minha Fazenda fez Antônio de Barros Bezerra e Manuel Preto 
Valdez, tanto que acabarem os anos de seu contrato, que ficará correndo pelos ditos assentistas pelo mesmo preço e no dito tempo de vinte anos, e com as mesmas direções faculdades e liberdades que lhes foram concedidas.

Em março de 1682, o rei confirmava o assento. Dois elementos chamam a atenção em relação ao assento celebrado em 1682. Em primeiro lugar a presença de 'velhos' envolvidos no tráfico com o Maranhão, como Pedralves Caldas, "abastado capitalista de Lisboa”, segundo José Ribeiro do Amaral, e Manuel Preto Valdez. Em segundo lugar, a íntima vinculação do tráfico maranhense com a Guiné, ao se pressupor a impossibilidade de comerciar com Angola e ao se estabelecer um vínculo formal com o contrato de Cacheu. Esse contrato, chamado "de Cacheu e do comércio da Guiné", fora estabelecido em 1676. De acordo com António Carreira, com o fim do contrato da Companhia de Cacheu, em 1682, "os sócios desta empresa conseguiram transferir os seus direitos" para a Companhia do Maranhão. O contrato de Cacheu, o segundo estabelecido pela Coroa para a região, fora celebrado com o objetivo de reedificar, fortificar e armar a praça de Cacheu, além de estimular o escoamento de seus gêneros e escravos (incluindo-se aí os moradores). Para tanto, o contrato estipulava uma série de vantagens fiscais, além de declarar a liberdade do comércio para os moradores de Cacheu e do arquipélago de Cabo Verde. Como já foi dito, a duração inicial do contrato era de seis anos, o que coincide com a própria criação da Companhia de Comércio do Maranhão, da qual, aliás, também participava Manuel Preto Valdez. ${ }^{18}$

Isso significa que, com a instituição da Companhia de Comércio do Maranhão, o príncipe procurava seguramente resolver não só os problemas da força de trabalho no Maranhão — em razão das leis de liberdade de 1680 mas igualmente conectar essa região com o desenvolvimento da praça de Cacheu e da própria Guiné. De fato, a segunda metade do século XVII assiste à consolidação dos interesses da Holanda, França e Inglaterra na região, ao passo que o domínio português se consolida em outras áreas do continente africano. Justamente, um dos mecanismos de intervenção das potências européias fora a criação de companhias de comércio. A idéia de uma conexão entre a Guiné e o Maranhão torna-se explícita em vários momentos. Em 1685, o rei ordenava ao Conselho Ultramarino que analisasse questões relativas ao "comércio de Cacheu e Maranhão"; nos documentos anexos falava-se no "contrato de Maranhão e Cacheu”. Nas discussões em torno da liquidação da Companhia do Maranhão e da de Cacheu, em 1686, a Junta dos Três Estados, que 
examinara a questão, deixava claro que os dois contratos eram "conseqüência um de outro" ou "co-respectivos".

A intenção parecia ser, assim, por um lado, estabelecer uma conexão atlântica, que tinha por objetivo resolver os problemas decorrentes da proibição da escravização e da escravidão indígenas no Estado do Maranhão e ao que parece procurar consolidar a presença portuguesa na Guiné. Mas não se tratava de uma conexão do Atlântico sul — região que tem recebido muita atenção dos historiadores nos últimos tempos - e sim do que poderíamos chamar de Atlântico norte ou, melhor, de Atlântico equatorial. Como já discutiu Alírio Carvalho Cardoso, a existência de uma rota norte se pensara desde o início da conquista do Maranhão. São vários os escritos dos primeiros conquistadores, como Manuel de Sousa de Eça ou Simão Estácio da Silveira, que insistiram na possibilidade de estabelecer uma via - através do Amazonas, em direção à Península Ibérica — para escoamento da prata do Peru, que, no século XVII, se acreditava muito próximo ao Maranhão. Além do mais, desde o início se percebera que a navegação da costa leste-oeste da América portuguesa era extremamente difícil, o que dificultava a conexão do Maranhão com as capitanias centrais do Estado do Brasil, como Bahia ou Pernambuco. Já em 1626, o capitão da capitania do Ceará, Martim Soares Moreno, escrevia lembrando que "do Maranhão para aquela dita capitania [Ceará] é a costa inavegável por respeito das águas e ventos correrem sempre em contrário ... e se põem 5 a 6 meses no caminho, o que não é da dita capitania do Ceará para Pernambuco, porque se vai em 15 dias, assim por mar como por terra, por onde há já caminho aberto". ${ }^{19}$

Porém, é importante insistir que o suposto desenvolvimento dessa rota não estava vinculado somente ao estímulo da lavoura de açúcar ou de tabaco para exportação. O contrato do Maranhão deixa claro que os escravos africanos serviriam para o desenvolvimento das lavouras dos moradores, o que incluía - e a Coroa sabia disso muito bem — os diversos produtos que se acreditava somente a Amazônia podia produzir naquele momento, como cacau e cravo de casca, entre outros. Ao longo do século XVII, foram inúmeras as tentativas (muitas delas fracassadas) de cultivo dos gêneros da região. Não sem razão, a cláusula quinta do contrato estabelecia a obrigação dos assentistas de enviar "pessoas a sua custa que tenham experiência do cacau, baunilha e outras drogas que há naquele Estado para as descobrirem e ensinarem a cultivar, de modo que os moradores se aproveitem delas".

Entretanto, as intenções da Coroa foram baldadas com uma rebelião a chamada revolta de Beckman - que ensejou o fim do contrato do Mara- 
nhão. Em fevereiro de 1684, os moradores de São Luís se levantaram contra a autoridade do governador (naquele momento residente em Belém do Pará), contra o estanco e contra os padres da Companhia de Jesus. ${ }^{20}$ Suprimida a rebelião em 1685, o novo governador, Gomes Freire de Andrade, mandou chamar os oficiais da Câmara de São Luís e de Belém para "se ajustar tudo o que V.M. foi servido encarregar-me, sobre a introdução dos negros neste Estado e sobre as mais ordens tocantes à conservação dele para o bem destes moradores e serviço de V.M." (como se lhe havia ordenado em seu regimento). Em outubro de 1685, Freire de Andrade escrevia novamente à Coroa dando conta do que fora discutido com as Câmaras. A carta revela, por um lado, a íntima ligação entre as leis de liberdade e a importação de escravos africanos por contratistas. Por outro, revela igualmente a dificuldade de estabelecer uma rota escravista sem a intervenção da própria Coroa. Assim, o governador relatava que lembrara aos oficiais que já "que V.M. lhes não havia de permitir em tempo algum o cativeiro dos índios, e que só por contrato haveria quem metesse escravos no Estado, resolvessem se queriam continuar o que tinham, ainda que fosse de menor duração, ou alterando-lhe algumas condições que fossem prejudiciais aos moradores e assentistas”. Um mês depois, entretanto, a Câmara de Belém escrevia ao rei advertindo que o estanco fora "o instrumento mais cruel que teve esta conquista para de todo ficar arruinada e tão pobre".

Resumindo o debate com as Câmaras, Gomes Freire de Andrade chegava à conclusão de que os moradores estavam impossibilitados de pagar os escravos, pois "estão estas povoações muito atenuadas de cabedais". Finalmente, despido de qualquer reserva, propunha, considerando o interesse do rei no aumento do Maranhão e "reconhecendo como por impossível que o possa haver sem que os moradores tenham escravos", que se autorizasse o resgate de índios prisioneiros das guerras intertribais. Sua justificativa não podia ser mais simples, "pois se não dará maior razão para que sem causas tão verificadas se permita o mesmo [resgates] na costa da Guiné e Angola e se não conceda no Maranhão". O fato é que finalmente o contrato foi levantado. A Coroa terminou cedendo, pois, apesar da anterior determinação de não "permitir em tempo algum o cativeiro dos índios", em 1688 o rei revogava a lei de liberdade de 1680, autorizava os resgates de índios, e definia os casos de guerra justa no Maranhão (dois anos antes instituíra-se o "Regimento das Missões", que conferia aos missionários o poder temporal sobre as aldeias de índios livres). ${ }^{21}$ 


\section{UMA HISTÓRIA EM FRAGMENTOS: OS NÚMEROS DO TRÁFICO}

Qualquer tentativa de estabelecer números seguros para o tráfico negreiro seiscentista, como aliás para toda a navegação para o Estado do Maranhão e Pará, esbarra no caráter fragmentário das fontes. Apesar dos assentos estabelecidos, a documentação não fornece registros sistemáticos, nem garantias da chegada dos navios e do número de escravos de fato desembarcados e vendidos, como, aliás, já há tempos havia assinalado Arthur Cezar Ferreira Reis. Porém, embora claramente os assentos e contratos sejam as formas principais de importação de africanos no Maranhão, houve tentativas de envio de escravos para a região, que poderíamos chamar de isoladas. O que sem dúvida chama a atenção para o século XVII (o que é comparável com a experiência de meados do século XVIII) é a procedência dos escravos, fundamentalmente da Guiné e da Costa da Mina, fato, aliás, já apontado por alguns autores, e que tanto preocupou estudiosos que procuraram entender a dinâmica e a especificidade dos cultos afro-brasileiros na Amazônia e no Maranhão.

A documentação não é clara quanto aos termos 'Guiné' e 'Mina'. Em alguns casos, usam-se os dois termos para designar o mesmo carregamento. Fica claro que, durante o tempo da Companhia de Comércio do Maranhão, em razão da explícita relação que se estabelecera com a reabilitação da praça de Cacheu, a origem dos escravos estava seguramente restrita à Guiné-Bissau. Nos anos posteriores, em que os assentos se fazem com a Companhia de Cabo Verde e Cacheu e com os mercadores Antônio Freire de Ocanha e Manuel Francisco Vilar, 'Guiné' e 'Mina' aparecem indistintamente, indicando provavelmente a área mais ampla da costa da Senegâmbia ao golfo da Guiné. Segundo Mariza de Carvalho Soares, desde finais do século XV a Mina se destaca do conjunto da Guiné, "garantindo uma existência própria em relação ao restante da costa ocidental”. O que fica claro é que a Companhia de Cabo Verde e, principalmente, os assentistas Antônio Freire de Ocanha e Manuel Francisco Vilar transitavam tanto pela 'Guiné' como pela 'Mina'. Segundo António Carreira, a Companhia de Cabo Verde e Cacheu recebera autorização para, além da Guiné, manter postos comerciais mais ao sul (até o Cabo Lopez). O que é notável, de qualquer modo, é a 'ausência' de escravos angolanos durante o final do século XVII e início do século XVIII. A própria Coroa havia assumido a dificuldade de estabelecer uma rota entre Angola e o Maranhão, ao firmar o contrato da Companhia de Comércio do Maranhão e sua vinculação com o de Cacheu, como já vimos. Porém, as dificuldades pelas quais pas- 
savam as operações do tráfico em Angola, principalmente em finais do século XVII, seguramente tornaram essa opção ainda mais inviável para o envio de escravos ao Maranhão. ${ }^{22}$

As Tabelas 1 e 2 e os Quadros 1 e 2 sistematizam os dados encontrados sobre o tráfico para o estado do Maranhão e Pará.

\section{Tabela 1}

Contratos e assentos celebrados pela Coroa $(1680-1706)^{23}$

\begin{tabular}{|c|c|c|c|c|c|}
\hline & Ano & Contratantes & $\begin{array}{c}\text { Número de } \\
\text { escravos }\end{array}$ & Origem & Observações \\
\hline 1 & 1680 & Pedralves Caldas & - & [Guiné] & não implementado \\
\hline 2 & 1680 & Manuel Preto Valdez & 500 a 600 & Guiné & não implementado \\
\hline 3 & 1680 & José Ardevicus & $\begin{array}{c}600 \\
\text { (em } 20 \text { meses) }\end{array}$ & Angola & não implementado \\
\hline 4 & 1682 & Companhia do Maranhão & $\begin{array}{c}10 \text { mil } \\
(\mathrm{em} 20 \text { anos })\end{array}$ & $\begin{array}{c}\text { Guiné } \\
\text { [e Angola] }\end{array}$ & \\
\hline 5 & 1692 & Companhia de Cabo Verde e Cacheu & 145 (em 1693) & $\begin{array}{l}\text { Mina e } \\
\text { Guiné }\end{array}$ & \\
\hline 6 & 1693 & Companhia de Cabo Verde e Cacheu & 145 (em 1694) & [Guiné] & não implementado \\
\hline 7 & 1695 & Companhia de Cabo Verde e Cacheu & 145 [em 1695?] & [Guiné] & - \\
\hline 8 & 1696 & Antônio de Ocanha e Manuel Vilar & - & $\begin{array}{l}\text { [Mina e } \\
\text { Guiné] }\end{array}$ & - \\
\hline 9 & 1698 & Antônio de Ocanha e Manuel Vilar & & & $\begin{array}{l}\text { referência ao envio } \\
\text { de escravos em } \\
\text { razão das bexigas; } \\
\text { contrato com } \\
\text { Ocanha e Vilar }\end{array}$ \\
\hline 10 & 1702 & Antônio de Ocanha e Manuel Vilar & 218 (ate 1699 ) & [Mina] & - \\
\hline 11 & 1705 & Antônio de Ocanha e Manuel Vilar & - & Mina & - \\
\hline
\end{tabular}


Tabela 2

Navios que chegaram ao Estado do Maranhão ${ }^{24}$

\begin{tabular}{|c|c|c|c|}
\hline Ano & $\begin{array}{c}\text { Número de } \\
\text { escravos }\end{array}$ & Procedência & Observações \\
\hline 1671 & 50 & Angola & $\begin{array}{l}\text { o governador Pedro César de Meneses levou } 50 \text { escravos } \\
\text { de Angola para construir o engenho de anil }\end{array}$ \\
\hline 1671 & {$[400]$} & Angola & $\begin{array}{l}\text { duas naus holandesas chegam a São Luís, mas são } \\
\text { impedidas de comerciar com a população pelo governador }\end{array}$ \\
\hline c. 1673 & - & Guiné & $\begin{array}{l}\text { capitão Domingos Lourenço, nau Nossa Senhora } \\
\text { do Rosário e Almas }\end{array}$ \\
\hline 1682 & - & [Guiné] & $\begin{array}{l}\text { chegada de Pascual Pereira Jansen (estanco) ao Maranhão } \\
\text { — contrato } 4\end{array}$ \\
\hline 1684 & 200 & Guiné & $\begin{array}{l}\text { navio do estanco chega a São Luís durante a revolta } \\
\text { - contrato } 4\end{array}$ \\
\hline $1684-85$ & $\begin{array}{l}\text { "poucos } \\
\text { escravos" }\end{array}$ & [Guiné] & navio do estanco chega a São Luís - contrato 4 \\
\hline 1685 & - & [Guiné] & $\begin{array}{l}\text { o capitão Silvestre da Silva chega ao Estado, pago pelo } \\
\text { estanco, que já havia sido abolido - contrato } 4\end{array}$ \\
\hline 1690 & - & Angola & $\begin{array}{l}\text { o governador Antônio de Albuquerque Coelho de Carvalho } \\
\text { refere-se a um navio vindo de Angola que teria naufragado } \\
\text { na costa do Pará }\end{array}$ \\
\hline 1693 & 139 & Mina e Guiné & $\begin{array}{l}\text { assento com a Companhia de Cabo Verde e Cacheu; capitão } \\
\text { Manuel Luís - contrato } 5\end{array}$ \\
\hline 1695 & {$[103]$} & [Guiné] & $\begin{array}{l}\text { assento com a Companhia de Cabo Verde e Cacheu; } \\
\text { vendidos aos senhores, lavradores e distribuídos } \\
\text { "por particulares" - contrato } 7\end{array}$ \\
\hline 1696 & 18 & - & $\begin{array}{l}\text { provavelmente assento; escravos vendidos aos senhores de } \\
\text { engenho e lavradores - provavelmente contrato } 8\end{array}$ \\
\hline 1698 & 108 & Mina & $\begin{array}{l}\text { assento com Antônio Freire de Ocanha e Manuel Francisco } \\
\text { Vilar; o capitão Diogo da Costa deveria entregar } 218 \\
\text { escravos; uma das naus queimou na costa da Mina } \\
\text { - contrato } 9\end{array}$ \\
\hline 1702 & 110 & [Mina $]$ & $\begin{array}{l}\text { assento com Antônio Freire de Ocanha e Manuel Francisco } \\
\text { Vilar; capitão Diogo da Costa — contrato } 10\end{array}$ \\
\hline 1705 & 153 & Mina & $\begin{array}{l}\text { assento feito com Antônio Freire de Ocanha e Manuel } \\
\text { Francisco Vilar; capitão Diogo da Costa - contrato } 11\end{array}$ \\
\hline
\end{tabular}




\section{Quadro 1}

Navios com chegada incerta ao Estado do Maranhão ${ }^{25}$

\begin{tabular}{|c|c|l|}
\hline Ano & Procedência & \multicolumn{1}{c|}{ Observações } \\
\hline 1672 & Angola & $\begin{array}{l}\text { Pedralves Caldas negocia enviar escravos ao Maranhão com o bispo } \\
\text { de Angola }\end{array}$ \\
\hline 1678 & Angola & $\begin{array}{l}\text { O capitão Manuel da Costa Cordeiro requer permissão para } \\
\text { conduzir escravos de Angola; nau São João Batista }\end{array}$ \\
\hline 1679 & $\begin{array}{l}\text { Angola } \\
\text { Fixa }\end{array}$ & $\begin{array}{l}\text { Antônio de Castro Guimarães, João de Sousa de Castro e Guilherme } \\
\text { pretendem enviar um navio ao Maranhão; nau Jesus, Maria, José }\end{array}$ \\
\hline Angola & $\begin{array}{l}\text { os proprietários do navio Nossa Senhora dos Mártires pretendem } \\
\text { enviar um navio ao Maranhão }\end{array}$ \\
\hline
\end{tabular}

Quadro 2

Navios que não chegaram ao Estado do Maranhão ${ }^{26}$

\begin{tabular}{|l|c|l|}
\hline Ano & Procedência & \multicolumn{1}{c|}{ Observações } \\
\hline 1681 & Angola & $\begin{array}{l}\text { o capitão Diogo de Lopes foi impedido de enviar um navio ao } \\
\text { Maranhão pelos contratantes de Angola }\end{array}$ \\
\hline 1694 & Guiné & $\begin{array}{l}\text { assento com a Companhia de Cabo Verde e Cacheu; o navio } \\
\text { naufragou — contrato 6 }\end{array}$ \\
\hline 1699 & Mina & $\begin{array}{l}\text { assento com com Antônio Freire de Ocanha e Manuel Francisco } \\
\text { Vilar; a nau perdeu-se na Costa da Mina — contrato 9 }\end{array}$ \\
\hline 1704 & Mina & Referência à perda de um navio que tinha ido à costa da Mina \\
\hline
\end{tabular}

É evidente a importância do tráfico no final do século XVII, que passa a se organizar em razão dos elementos apontados anteriormente - as epidemias, as leis de liberdade indígena e os interesses da Fazenda real na região. A organização do tráfico, como revela a importância dos contratos e assentos, se faz fundamentalmente por intervenção e iniciativa da própria Coroa, daí a particularidade do envio de africanos de forma geral, estabelecido para atender a demandas circunstanciais - como no caso das bexigas e das necessidades da Fazenda real - e para resolver os problemas decorrentes do uso preferencial de trabalhadores indígenas no Estado do Maranhão. É que não se pode pensar a utilização dos escravos africanos no Maranhão separada do uso dos indígenas, algo que os moradores e a própria Coroa sabiam muito bem, como o haviam experimentado os próprios moradores das capitanias açucareiras, no processo de 'substituição' da mão-de-obra indígena pela mão-de- 
obra africana, a partir de finais do século XVI. O tráfico para o Maranhão e Pará definitivamente organizava-se a partir da Coroa. Diferente era o de outras praças, onde existia uma classe de negociantes que financiava o empreendimento, uma frota que o viabilizava, uma infra-estrutura que lhe dava suporte e, principalmente, onde existia, como exemplarmente define Nireu Cavalcanti, "o fundamental elemento do comércio: os compradores ávidos por muitos e muitos escravos".

Nesse sentido, o tráfico africano para o Estado do Maranhão não pode ser pensado apenas a partir de uma lógica do mercado escravista, que permite entender realidades como a da Bahia e de Pernambuco, ou mesmo do Rio de Janeiro de finais do século XVII e início do século XVIII. Por um lado, segundo Carl Hanson, desde a década de 1660, a coroa portuguesa insistiu na revitalização econômica de sua 'periferia'. Entretanto, mais do que integrar a economia do Estado do Maranhão à do reino por meio do 'mercado africano', promovendo o seu 'desencravamento', como quer Luiz Felipe de Alencastro, tratava-se antes de resolver os problemas que a própria ocupação e a especificidade da região haviam gerado.

Além do mais, como já indicado anteriormente, a relação entre plantation açucareira e escravidão africana não pode ser pensada como modelo para o Maranhão, por mais que os moradores e autoridades invocassem o exemplo brasileiro para solicitar o envio de escravos ao Estado. Como mostra a experiência do estanco, o africano era pensado também para desenvolver a lavoura de produtos locais. No seu parecer sobre a introdução de um assento de Cabo Verde, referido anteriormente, João de Moura defendia exemplarmente que seria de muita utilidade se enviasse à região uma "pessoa de bom discurso e inteligência na cultura natural dos campos, para que com a experiência penetre a daquele clima, e penetrada a divulgue àqueles moradores, porque só assim virá em perfeito conhecimento dos segredos que em si inclui a agricultura do Pará". O cultivo dos gêneros locais, assim, era também pensado a partir do uso da mão-de-obra africana. Exemplar nesse sentido era a cultura do anil do Maranhão. O primeiro empreendimento dessa plantação fora feito com o governador Pedro César de Meneses, o qual, segundo o padre Bettendorf, trouxera cinqüenta escravos de Angola para trabalhar no seu benefício (ver Tabela 2). Em 1693, Francisco do Amaral Soares, que montara um engenho de anil, comprara cinco escravos a 160 mil réis cada; Domingos Falcão, "lavrador de anil", comprara apenas um escravo do mesmo lote. ${ }^{27}$

Quanto ao número de escravos importados até o fim do reinado de dom Pedro II, temos pouco menos de mil. Seguramente, os números finais são al- 
go maiores, já que para alguns carregamentos seguros, como os do estanco de 1682 e alguns dos assentos, não há qualquer referência à quantidade de escravos. Provavelmente o número total não passe de 1.500 escravos, entre a década de 1670 e o primeiro decênio do século XVIII. Para o período anterior, praticamente não há indicações de carregamentos de escravos. Comparado com outras regiões da América portuguesa, como Bahia e Pernambuco, fica claro que o volume do tráfico é ínfimo. Entretanto, as estimativas de população que, para o século XVII, como já apontara há muito tempo Fran Paxeco, "revelam-se muito deficientes", indicam que a população portuguesa na região era também pequena. Os dados disponíveis para todo o Estado são muito poucos e estão sistematizados no Tabela 3.

Tabela 3 - População do Estado do Maranhão ${ }^{28}$

\begin{tabular}{l|l|c|c|c}
\hline & \multicolumn{1}{|c|}{ São Luís } & Tapuitapera & Belém & Totais \\
\hline $\begin{array}{l}\text { Manuel Soutomaior } \\
\text { Papel sobre ...”, 1663 }\end{array}$ & \multicolumn{2}{|l|}{$\begin{array}{l}\text { 700 moradores repartidos pelas capitanias do Pará } \\
\text { e Maranhão }\end{array}$} & 700 \\
\hline $\begin{array}{l}\text { João de Moura } \\
\text { “Collonia porugueza...”, 1684“ }\end{array}$ & $\begin{array}{l}800 \text { vizinhos } \\
407 \text { fogos } \\
150 \text { soldados }\end{array}$ & & $\begin{array}{l}200 \text { homens que } \\
\text { podem tomar em } \\
\text { armas } 150 \text { fogos }\end{array}$ & 1.150 \\
\hline $\begin{array}{l}\text { Manuel Guedes Aranha } \\
\text { "Papel político...”, 1685 }\end{array}$ & $\begin{array}{l}\text { mais de } \\
\text { mil vizinhos }\end{array}$ & 400 vizinhos & 500 moradores & 1.900 \\
\hline $\begin{array}{l}\text { João de Sousa Ferreira } \\
\text { “América abbreviada..., } 1693\end{array}$ & 600 vizinhos & 300 vizinhos & 400 moradores & 1.300 \\
\hline
\end{tabular}

Se os dados referem-se apenas à população portuguesa e adulta (provavelmente masculina), em geral a única indicada na documentação, isso significa que o número total de moradores nas cidades de São Luís e Belém e na vila de Tapuitapera era maior (embora não tão numerosa como alguns autores querem crer, a exemplo de José Ribeiro do Amaral). Também há que se lembrar que muitos moravam em suas lavouras e engenhos, nos rios próximos às cidades. De qualquer modo, a comparação com os números do tráfico indica que, proporcionalmente, o volume de escravos africanos não era tão desprezível como se consagrou na historiografia. Como vimos, o que aparece é uma concentração de envio de africanos nas décadas finais do século XVII. Ora, se levarmos em consideração o ano de 1693, quando, de acordo com o texto do padre João de Sousa Ferreira, a população do Estado chegava a 1.300, a vinda de um navio carregado de escravos podia chegar a representar em tor- 
no de dez por cento dos homens portugueses. É possível afirmar, portanto, que nas décadas de 1690 e de 1700 , em razão da concentração dos assentos celebrados pela Coroa, o crescimento do número de escravos - apesar do incipiente tráfico - seguramente ultrapassou o crescimento da própria população do Estado. Nesses anos, portanto, a importância relativa da presença africana na região não pode ser desconsiderada.

\section{EXPERIÊNCIAS AFRICANAS}

Mas, se a presença africana não pode ser desconsiderada em termos numéricos, igualmente não pode ser desprezada em suas inúmeras implicações. Emblematicamente, no navio do primeiro assento feito com a Companhia de Cabo Verde e Cacheu, o patacho Nossa Senhora da Conceição e São João Batista, que chegara ao Estado em 1693, frei Bernardino das Entradas recebia uma denúncia feita por Lourenço Rodrigues, "mancebo" do navio, contra João Segundo, "tapanhuno", cativo de Jacob Egres, "estrangeiro hamburguês, homem de negócio na cidade do Grão-Pará”. Vindo com Lourenço de Cabo Verde, João Segundo teria lhe dito que tinha "certa coisa" que lhe protegia do fogo e de armas, que eram duas bolsas uma menor que a outra. Já no Pará, um companheiro de Lourenço lhe tirou a bolsa da caixa e abrindo-a achou uma pedra negra e pensando que eram coisas do demônio a jogou ao fogo, o que o próprio Lourenço só soubera depois.

O caso de João Segundo, obviamente, não era o único, revelando que, apesar de Luiz Mott não ter encontrado referências a rituais de origem africana no Maranhão colonial (embora sua pesquisa se concentre mais no século XVIII), ainda no século XVII o tráfico permitira a circulação de práticas religiosas entre a África e a região. Na década de 1690, graças à ação de frei Bernardino, foram denunciados vários africanos escravos em várias partes do Estado do Maranhão. Na capitania do Caeté, situada entre a capitania de Tapuitapera e a do Pará, Antônio de Matos morador da vila de Sousa denunciava a Sebastião, "negro tapanhuno", cativo de Belquior Gomes, morador da mesma vila. Segundo Matos, era público no Caeté que Sebastião era "curador e adivinhador", ele próprio o tendo visto uma vez fazendo uma adivinhação sobre uma quantia furtada. Já na Vila Nova do Icatu (capitania do Maranhão), José Pinheiro Marques, casado, avaliador, inquiridor e contador no juízo secular, denunciava a Jorge, "negro tapanhuno da África", cativo de Antônio de Sousa Soeiro. Segundo Pinheiro Marques, sabendo da fama de Jorge como 
feiticeiro, pedira-lhe uma mezinhas para que "seus inimigos o não pudessem ofender". Pouco tempo antes, o mesmo Jorge havia sido denunciado em São Luís por várias pessoas que o acusavam de feiticeiro. Segundo Ana de Araújo, João Barreiros mandara fazer feitiços por um preto chamado Jorge (indica-se que era escravo de Antônio de Sousa Soeiro), para matar Ambrósio Pereira, pois lhe tinha medo por ter andado com a sua mulher. Já Clara, "serva da dita Ana de Araújo", de 25 anos, confirmara a história de sua senhora, detalhando ainda que o feitiço era um cordão, que, quando apertado, Ambrósio Pereira definhava.

Para além das implicações nas práticas religiosas, a presença de escravos africanos, como em qualquer parte da América portuguesa, desencadeava um sem-número de relações interétnicas. As denúncias de solicitação contra o frei franciscano Pedro do Espírito Santo, por exemplo, revelam a existência de pessoas como Sabina, escrava de Estevão Gomes Malheiros, "filha de índio e preta, ou vice-versa, cafuza"; ou Lucrecia, "cafuza, solteira, filha de Madalena, preta, e seu pai Nicolau, índio da terra", ambos "servos" do capitão Norberto Gonçalves; ou, finalmente, de Margarida, "cafuza, solteira, filha de Antônio, índio da terra e Susana, preta”, escravos de André Cordeiro, já defunto, e de sua mulher, Barbosa Goulart. Os livros de registro de casamentos e batismos da igreja jesuítica de São Francisco Xavier, em Belém, revelam parte dessas complexas relações estabelecidas entre africanos e nativos que habitavam as cidades ou suas proximidades. Em fevereiro de 1687, o padre Francisco Ribeiro casava Miguel com Luzia “do gentio da Guiné”, escravos do colégio de Santo Alexandre, tendo como padrinhos a Pedro e sua mulher Guiomar, também escravos do colégio. Em julho de 1703, casavam-se Vital, “cafuzo”, escravo do capitão-mor João Duarte Franco, com Catarina, "índia forra da aldeia de Iguna", sendo testemunhas Sebastião "preto", Pedro "preto", e João Gomes, "branco". Apesar das precauções que se deve tomar quanto às relações de compadrio, principalmente no que respeita à escolha dos padrinhos, não deixam de ser significativos batismos como o de Gregório, filho de Mandû e Antônia, da aldeia de Meruí, cujos padrinhos teriam sido Domingos, "preto de Joana Melo" e Maria “índia”. Em maio de 1699, o padre Bento de Oliveira batizava a Benedito, inocente, filho de João Maciel e de Antônia, da aldeia de Moribira, tendo como padrinhos a Manuel da Costa e Ana "preta de Amador Lourenço".

Finalmente, cabe chamar a atenção aqui para o caso do "preto" José Lopes, ao qual também se refere Vicente Salles. Originário de Cabo Verde, José Lopes, que segundo o padre Bettendorf teria sido o feitor dos negócios do ca- 
pitão-mor Hilário de Sousa, tivera uma singular importância nos sertões amazônicos. Não se sabe se foi cativo ou não, mas o fato é que chegou a comandar várias nações indígenas do Rio Negro, obedecendo a ordens do governador, segundo ele próprio relatava em duas cartas, escritas de Anibá, no Rio Negro, em 1700. Em razão de seus serviços, relatados ao rei pelo próprio governador, o soberano mandou lhe agradecer e dar uma medalha de ouro. Mais ainda, o rei mandou que se lhe passasse patente de "capitão do sertão e distrito das missões dos mercedários". Entretanto, anos depois, José Lopes entrou em conflito com o loco-tenente Fernão Carrilho, que então governava o Maranhão, e que o acusava de se ter feito "senhor absoluto dos sertões, resgatando por si e por intervenção de outras muitas pessoas, quantos escravos quer". Depois de sua morte, o soberano mandou devassar das guerras comandadas por José Lopes contra nações indígenas, sobre as quais pesava a suspeita de terem sido injustas. ${ }^{29}$

Não se trata aqui de discutir as relações e as práticas culturais oriundas dos contatos entre os diversos grupos que compunham a população do Estado do Maranhão, o que, felizmente, tem recebido a atenção dos estudiosos, principalmente em relação à experiência africana a partir de meados do século XVIII. ${ }^{30} \mathrm{O}$ que é fundamental é insistir na necessidade de reavaliar a importância dos escravos africanos no antigo Estado do Maranhão e Pará, mesmo no século XVII e início do século XVIII. Afinal, a inexistência de um tráfico regular e volumoso conectado aos circuitos sul-atlânticos, diferente de outras partes da América portuguesa, definitivamente não pode servir de empecilho, nem de modelo, para se entender os significados e as implicações da presença africana na região.

\section{NOTAS}

${ }^{1}$ Este texto é parte de uma pesquisa que desenvolvo junto ao Departamento de História da Universidade Federal do Pará, sobre as políticas da coroa portuguesa para o Estado do Maranhão, de 1640 a 1706. Agradeço o auxílio e os comentários de José Maia Bezerra Neto e Décio de Alencar Guzmán. Agradeço igualmente a Aldrin Moura de Figueiredo, que, além dos comentários, sugeriu a expressão "Atlântico equatorial" para definir o tráfico negreiro para a Amazônia seiscentista.

${ }^{2}$ Ver, por exemplo: ALDEN, Dauril. "El indio desechable en el Estado de Maranhão durante los siglos XVII y XVIII”. América Indígena, México (DF), v.XLV, n.2 (abr.-jun. 1985), p.427-46; BRUNO, Ernani Silva. História do Brasil. Geral e regional — Amazônia. São Paulo: Cultrix, 1966, v.I, p.71-93; CAVALCANTI FILHO, Sebastião. A questão jesuítica no Ma- 
ranhão colonial (1622-1759). São Luís: Sioge, 1990, p.22-6; FARAGE, Nádia. As muralhas dos sertões: os povos indígenas no Rio Branco e a colonização. Rio de Janeiro: Paz e Terra/ Anpocs, 1991, p.23-53; FURTADO, Celso. Formação econômica do Brasil. 22.ed. São Paulo: Cia. Ed. Nacional, 1987, p.65-8 e 89-92; GROSS, Sue Ellen Anderson. The economic life of the Estado do Maranhão e Grão-Pará, 1686-1751. Tese de doutorado (História), Tulane University, 1969, p.192-207; LOPES, Raimundo. O torrão maranhense. Rio de Janeiro: Typographia do Jornal do Commercio, 1916, p.216-7; ACEVEDO MARIN, Rosa Elizabeth. "Agricultura no delta do rio Amazonas: colonos produtores de alimentos em Macapá no período colonial". In: (Org.) A escrita da história paraense. Belém: NAEA, 1998, p.53-91; MEIRELES, Mário Martins. História do Maranhão. 3.ed. São Paulo: Siciliano, 2001, p.1918; MENDONÇA, Octávio. Presença portuguesa na Amazônia. Belém: Conselho Estadual de Cultura, 1984, p.23-4; OLIVEIRA, Adélia Engrácia de. “Ocupação humana”. In: SALATI, Enéas et al. Amazônia: desenvolvimento, integração e ecologia. São Paulo: Brasiliense; Brasília: CNPq, 1983, p.170-1; PRADO JR., Caio. História econômica do Brasil. 35.ed. São Paulo: Brasiliense, 1987, p.69-75; REIS, Arthur Cezar Ferreira. A política de Portugal no vale amazônico [1940]. Belém: Secult, 1993, p.91-110; REIS, Arthur Cezar Ferreira. Síntese de história do Pará. 2.ed. Belém: Amazônia Ed. Culturais, 1972, p.57-63; TOCANTINS, Leandro. Amazônia: natureza, homem e tempo. Uma planificação ecológica. 2.ed. Rio de Janeiro: Civilização Brasileira, 1982, p.44-54; TRIBUZI, Bandeira (José Tribuzi Pinheiro Gomes). Formação econômica do Maranhão: uma proposta de desenvolvimento. São Luís: Fipes, 1981, p.11-7; SILVA, Marilene Corrêa da. O paiz do Amazonas. Manaus: Ed. Un. AM, 1996, p.46, 83; SILVA, Moacyr Paixão e. Formação econômica do Amazonas (período colonial). In: CONGRESSO SUL-RIOGRANDENSE DE HISTÓRIA E GEOGRAFIA, III, Separata dos Anais..., 1940, p.31-7; SIMONSEN, Roberto. História econômica do Brasil. São Paulo: Cia. Ed. Nacional, 1937, p.162; SOUZA, Márcio. Breve história da Amazônia. 2.ed. Rio de Janeiro: Agir, 2001, p.70-1 e 86-7; SWEET, David. A rich realm of nature destroyed: the middle Amazon valley, 1640-1750. Tese de doutorado (História), University of Wisconsin, 1974, p.55-70; VIVEIROS, Jerônimo de. História do comércio do Maranhão (16121895). São Luís: Associação Comercial do Maranhão, 1954, v.I, p.67-9.

${ }^{3}$ VERGOLINO-HENRY, Anaíza; FIGUEIREDO, Arthur Napoleão. A presença africana na Amazônia colonial. Uma notícia histórica. Belém: Apep, 1990, p.27-8. Para José Maia Bezerra Neto, igualmente, associar a colonização portuguesa na Amazônia a uma economia extrativista e ao uso de mão-de-obra indígena tornou-se "comum" na historiografia. Para ele, se essa imagem não é descabida, ela seguramente constitui uma "leitura empobrecida" da realidade econômica. BEZERRA NETO, José Maia. Escravidão negra no Grão-Pará (Sécs. XVII-XIX). Belém: Paka-Tatu, 2001, p.17-8. PEREIRA, Manuel Nunes. "A introdução do negro na Amazônia”. Boletim Geográfico - IBGE, v.7, n.77, 1949, p.509; REIS, Arthur Cezar Ferreira. "O negro na empresa colonial dos portugueses na Amazônia”. Actas do Congresso Internacional de História dos Descobrimentos. Lisboa: Comissão Executiva das Comemorações da Morte do Infante Dom Henrique, v.V, II parte, 1961, p.347-53. No prefácio à primeira edição da obra de Vicente Salles, Ferreira Reis reitera esse argumento. REIS, Ar- 
thur Cezar Ferreira. "Prefácio". In: SALLES, Vicente. O negro no Pará: sob o regime da escravidão. 2.ed. Brasília: MinC; Belém: Secult, 1998, p.XI; SALLES, Vicente, op. cit., p.4-5; MACLACHLAN, Colin. "African slave trade and economic development in Amazonia, 1700-1800”. In: TOPLIN, Robert Brent (Org.) Slavery and race relations in Latin America. Westport: Greenwood Press, 1974, p.115-8; ALMEIDA, Maria Regina Celestino de. “Trabalho compulsório na Amazônia: séculos XVII-XVIII”. Revista Arrabaldes, ano I, n.2 (set.dez., 1988), p.103-5.

${ }^{4}$ ALDEN, Dauril. "Indian versus black slavery in the state of Maranhão during the seventeenth and the eighteenth centuries". Bibliotheca Americana, Coral Gables, v.1, n.3 (Jan. 1984), p.91-142; XIMENDES, Carlos Alberto. Economia e sociedade maranhense (16121755): elementos para uma reinterpretação. Assis: Dissertação de mestrado (História e Sociedade), Universidade Estadual Paulista, 1999, p.111; SARAIVA, António José. "Le père Antonio Vieira S.J. et la question de l'esclavage des noirs au XVIIe siècle”. Annales. Economies, sociétés, civilisations, Paris, $22^{\mathrm{e}}$ année, n.6 (nov.-dec. 1967), p.1290; VIEIRA, Antônio, S.J. “À câmara do Pará”. Pará, 12 de fevereiro de 1661. Cartas. Coordenadas e anotadas por João Lúcio de Azevedo. Lisboa: Imprensa Nacional/Casa da Moeda, 1997, v.I, p.558; TOMÁS, Domingos Antunes. “Sobre o Maranhaõ e Parà". Lisboa, 3 de novembro de 1679. Biblioteca da Ajuda [BA], cód. 50-V-37, f.397; VAINFAS, Ronaldo. Ideologia e escravidão: os letrados e a sociedade escravista do Brasil colonial. Petrópolis: Vozes, 1986, p.84-100. Sobre a legitimação da escravidão africana, ver também: LARA, Silvia Hunold. Campos da violência: escravos e senhores na capitania do Rio de Janeiro, 1750-1808. Rio de Janeiro: Paz e Terra, 1988, p.29-56; MARQUES, Rafael de Bivar. Feitores do corpo, missionários da mente. Senhores, letrados e o controle dos escravos nas Américas, 1660-1860. São Paulo: Companhia das Letras, 2004, p.19-83.

${ }^{5}$ SWEET, David, op. cit., p.79. As epidemias de bexiga continuaram assolando a região durante os séculos seguintes. A esse respeito, ver: MARQUES, César Augusto, op. cit., p.485; VIANNA, Arthur. As epidemias no Pará [1908]. 2.ed. Belém: UFPA, 1975, p.33-75; ALDEN, Dauril. "El indio desechable en el Estado de Maranhão durante los siglos XVII y XVIII", p.437-8; MEIRELES, Mário. "Apontamentos para a história da medicina no Maranhão". In: Dez estudos históricos. São Luís: Alumar, 1994, p.203-10; RAMINELLI, Ronald. “Testemunhos do despovoamento: Amazônia colonial”. Lisboa: Leituras série 3, n.6 (abr.-out. 2000), p.41-56; "Noticia dos sucessos, e expulçam dos P.P. da Companhia, do Estado do Maranhaõ. Authora, a Verdade". 8 de agosto de 1662. Biblioteca Nacional de Portugal [BNP], Reservados, COD 1570, p.181; BETTENDORF, João Felipe. Crônica da missão dos Padres da Companhia de Jesus no Maranhão [1698]. Belém: Fundação Cultural do Pará Tancredo Neves/Secretaria de Estado da Cultura, 1990, p.213; HERIARTE, Maurício de. “Descripção do Estado do Maranhão, Pará, Corupá e Rio das Amazonas” [1662-1667]. In:VARNHAGEN, Francisco Adolfo de. História geral do Brasil. 3.ed. São Paulo: Melhoramentos; Rio de Janeiro: INL, 1946, p.212. "Carta do Parâ”. 10 de abril de 1663. Instituto dos Arquivos Nacionais/Torre do Tombo [IAN/TT]. Província de Santo Antônio, Província, maço 18, n.33; Arquivo Histórico Ultramarino [AHU], Maranhão (Avulsos), cx. 4, doc. 469 (1663). 
${ }^{6}$ BETTENDORF, João Felipe, op. cit., p.585-9; ALDEN, Dauril \& MILLER, Joseph. “Out of Africa: the slave trade and the transmission of smallpox to Brazil". Cambridge (MA): Journal of Interdisciplinary History, v.18, n.2 (Autumn 1987), p.200-4 e 218-9; CURTIN, Philip. "Epidemiology and the slave trade". New York: Political Science Quarterly, v.83, n.2 (June 1968), p.193. Sobre tráfico negreiro e doenças, ver ainda: ASSIS, Marcelo Ferreira de. Tráfico atlântico, impacto microbiano e mortalidade escrava, Rio de Janeiro, c. 1790-c. 1830. Rio de Janeiro: Dissertação de Mestrado (História Social), Universidade Federal do Rio de Janeiro, 2002; Sobre as formas de resistência dos índios americanos às epidemias, ver: KELTON, Paul. "Avoiding the smallpox spirits: colonial epidemics and southeastern Indian survival”. Etnohistory, Durham, v.51, n.1, 2004, p.45-71; AMARAL, José Ribeiro do. Ephemerides maranhenses. Datas e factos mais notaveis da historia do Maranhão. São Luís: Typogravura Teixeira, s.d., p.37; AHU, Maranhão (Avulsos), cx. 9, doc. 925 (1696); a carta de Antônio de Albuquerque Coelho de Carvalho está incluída em AHU, Maranhão (Avulsos), cx. 9, doc. 928 (1696); AHU, cód. 274 (Consultas do Maranhão), f.114v (1697); a petição do procurador do Maranhão está incluída em $A H U$, Maranhão (Avulsos), cx. 9, doc. 981 (1699).

${ }^{7}$ AZEVEDO, João Lúcio de. Os jesuitas no Grão-Pará: suas missões e a colonização [1901]. Belém: Secult, 1999, p.134; "Carta dos oficiais da câmara de São Luís do Maranhão para o Conselho Ultramarino”. São Luís, 22 de agosto de 1665. AHU, Maranhão (Avulsos), cx. 4, doc. 499 (1665); AHU, Maranhão (Avulsos), cx. 4, doc. 506 (1665).

${ }^{8}$ Sobre a administração particular em São Paulo, ver: MONTEIRO, John Manuel. Negros da terra: índios e bandeirantes nas origens de São Paulo. São Paulo: Companhia das Letras, 1994; e AMBIRES, Juarez Donizete. Os jesuitas e a administração dos indios por particulares em São Paulo, no último quartel do século XVII. Dissertação de Mestrado (Literatura Brasileira), Universidade de São Paulo, 2000. Sobre a ordem que autorizou os resgates de índios, ver: "Livro Grosso do Maranhão" [LGM]. Anais da Biblioteca Nacional, Rio de Janeiro, v.66, 1948, p.97-101 (1688). Sobre a lei que autorizou os descimentos privados, ver: $A H U$, cód. 93 (Provisões), f.377-378 (1684). Uma cópia dessa ordem pode ser consultada em: Biblioteca Pública de Évora [BPE], cód. CXV/2-12, f.172-173v.

${ }^{9}$ AHU, Maranhão (Avulsos), cx. 9, doc. 925 (1696); AHU, cód. 274 (Consultas do Maranhão), f.114v (1697); AHU, cód. 268 (Cartas para o Maranhão), f.125 (1697); AHU, cód. 274 (Consultas do Maranhão), f.124v (1698).

${ }^{10}$ AHU, cód. 268 (Cartas para o Maranhão), f.77 (1691); AHU, Pará (Avulsos), cx. 3, doc. 306 (1692); AHU, cód. 274 (Consultas do Maranhão), f.87v (1692); AHU, cód. 274 (Consultas do Maranhão), f.88 (1692); CARREIRA, António. As Companhias pombalinas de navegação, comércio e tráfico de escravos entre a costa africana e o nordeste brasileiro. Bissau: Centro de Estudos da Guiné Portuguesa, 1969, p.18-23 e 305-8 (contrato da Companhia de Cacheu e Cabo Verde); IAN/TT, Conselho Ultramarino, Decretos, livro 1, f.143 (1691); IAN/TT, Conselho Ultramarino, Decretos, livro 1, f.144v (1691); AHU, Maranhão (Avulsos), cx. 9, doc. 925 (1695); AHU, cód. 296 (Contratos Reais), f.79-80 (1692); LGM, p.135 
(1692); AHU, Maranhão (Avulsos), cx. 8, doc. 858 (1693); "Parecer sobre se augmentar o Estado do Maranham fazendo-se assento para negros de Cabo Verde. Feyto por Joam de Moura" [1692-93]. BNP, Reservados, COD 1570, p.323-4. Sobre a presença "estrangeira" na Amazônia e na costa leste-oeste da América portuguesa, ver: CARDOSO, Alírio Carvalho. Insubordinados, mas sempre devotos: poder local, acordos e conflitos no antigo Estado do Maranhão (1607-1653). Dissertação de mestrado (História), Universidade Estadual de Campinas, 2002; CASTRO, Adler Homero Fonseca de. "O fecho do império: história das fortificações do Cabo do Norte ao Amapá de hoje”. In: GOMES, Flávio dos Santos (Org.) Nas terras do Cabo do Norte: fronteiras, colonização e escravidão na Guiana brasileira (séculos XVIII-XIX). Belém: Ed. Universitária da UFPA, 1999, p.129-93; COUTO Jorge. "As tentativas portuguesas de colonização do Maranhão e o projecto da França equinocial". In: VENTURA, Maria da Graça M. (Org.) A união ibérica e o mundo atlântico. Lisboa: Colibri, 1997, p.171-94; EDMUNDSON, George. "The Dutch on the Amazon and Negro in the seventeenth century. Part I — Dutch trade on the Amazon”. Oxford: English Historical Review, v.18, issue 72 (Oct. 1903), p.642-63; Idem, Part II — Dutch trade in the basin of the Rio Negro". Oxford: English Historical Review, v.19, issue 73 (Jan. 1904), p.1-25; LISBOA João Francisco. Crônica do Brasil colonial: apontamentos para a história do Maranhão. Petrópolis: Vozes; Brasília: INL, 1976, p.87-126; LORIMER, Joyce. English and Irish settlement on the River Amazon. 1550-1646. London: The Hakluyt Society, 1989; MARTINIERE, Guy. “A implantação das estruturas de Portugal na América (1620-1750)”. In: MAURO, Frédéric (Coord.) Nova história da expansão portuguesa. O império luso-brasileiro (1620-1750). Lisboa: Estampa, 1991, v.VII, p.103-69; REIS, Arthur Cezar Ferreira. "A ocupação portuguesa do vale amazônico”. In: HOLANDA, Sérgio Buarque de (Org.) História geral da civilização brasileira. 2.ed. São Paulo: Civilização Brasileira, 1963, v.I/1, p.25772; REIS, Arthur Cezar Ferreira. A política de Portugal no vale Amazônico; REIS, Arthur Cezar Ferreira. Limites e demarcações na Amazônia brasileira [1948]. Belém: Secult, 1993, 2v.; REIS, Arthur Cezar Ferreira. Síntese de história do Pará, p.11-8; WILLIAMSON, James Alexander. English colonies in Guiana and on the Amazon (1604-1668). Oxford: Clarendon Press, 1923.

${ }^{11}$ AHU, cód. 94 (Provisões), f.220 (1693); AHU, cód. 268 (Cartas para o Maranhão), f.102 (1693); FERREIRA, Roquinaldo Amaral. Transforming Atlantic slaving: trade, warfare and territorial control in Angola, 1650-1800. Tese de doutorado (História). University of California Los Angeles, 2004, p.40; o recenseamento do almoxarifado, datado de 14 de junho de 1696, está em: AHU, Maranhão (Avulsos), cx. 9, doc. 931 (1697); a carta de Antônio de Albuquerque Coelho de Carvalho, datada de 21 de junho de 1693, encontra-se em: $A H U$, Maranhão (Avulsos), cx. 8, doc. 869 (1693); AHU, cód. 268 (Cartas para o Maranhão), f.177v-178 (1702).

${ }^{12}$ Há que se lembrar, igualmente, que, em duas ocasiões - 1695 e 1702 — os moradores do Pará queixaram-se da distribuição desigual dos escravos entre as duas capitanias, o que levou o rei a insistir na necessidade de repartição dos escravos nos dois territórios. Ver: 
LGM, p.155-6 (1695); e LGM, p.225-6 (1702). A esse respeito, ver também: SALLES, Vicente, op. cit., p.24.

${ }^{13}$ A carta da Câmara de São Luís, datada de 12 de junho de 1693, encontra-se em: AHU, Maranhão (Avulsos), cx. 8, doc. 869 (1693); LGM, p.150 (1693); LGM, p.155 (1695); LGM, p.167 (1697); LGM, p.170 (1697); LGM, p.235 (1703).

${ }^{14}$ AHU, cód. 268 (Cartas para o Maranhão), f.156v (1700). Ver também: AHU, cód. 268 (Cartas para o Maranhão), f.121 (1696); AHU, cód. 268 (Cartas para o Maranhão), f.148v (1699); AHU, cód. 268 (Cartas para o Maranhão), f.152v (1700); AHU, cód. 268 (Cartas para o Maranhão), f.152v (1700); AHU, cód. 268 (Cartas para o Maranhão), f.153v (1700); AHU, cód. 268 (Cartas para o Maranhão), f.202v (1705); AHU, Pará (Avulsos), cx. 4, doc. 325 (1695); o recenseamento de 1696 encontra-se em: AHU, Maranhão (Avulsos), cx. 9, doc. 931 (1697); IAN/TT, Conselho Ultramarino, Decretos, livro 1, f.181 (1696); ver também: IAN/TT, Conselho Ultramarino, Decretos, livro 1, f.184v (1697).

${ }^{15}$ LGM, p.57-9 (1680); VIEIRA, Antônio, S.J. “Ao superior do Maranhão”. Lisboa, 2 de abril de 1680. Cartas, v.III, p.443; LGM, p.52 (1680); KIEMEN, Mathias, OFM. The Indian policy of Portugal in the Amazon region, 1614-1693. Washington (DC): The Catholic University of America Press, 1954, p.146; PACHECO, dom Felipe Condurú. História eclesiástica do Maranhão. São Luís: Departamento de Cultura do Maranhão, 1969, p.16; AZEVEDO, João Lúcio, op. cit., p.143; IAN/TT, Conselho Ultramarino, Decretos, livro 1, f.59-59v (1680); AHU, Maranhão (Avulsos), cx. 6, doc. 649 (1680); IAN/TT, Conselho Ultramarino, Decretos, livro 1, f.62v (1680).

${ }^{16}$ AHU, codex 296 (Contratos reais), f.39-41 (1680); AHU, codex 296 (Contratos reais), f.41 (1680); AHU, codex 296 (Contratos reais), f.41v (1681); AHU, codex 274 (Consultas do Maranhão), f.24 (1681); AHU, cód. 93 (Provisões), f.258 (1681); AHU, codex 49 (Consulta de partes), f.50-50v (1683); FERREIRA, Roquinaldo Amaral, op. cit., p.28; AHU, Maranhão (Avulsos), cx. 7, doc. 778 (1687).

${ }^{17}$ AHU, Pará (Avulsos), cx. 2, doc. 168 (1677); LGM, p.43 (1677); AHU, Maranhão (Avulsos), cx. 5, doc. 613 (1677). MARQUES, César Augusto, op. cit., p.265. Sobre as Companhias de Comércio, ver, por exemplo: DISNEY, Anthony. “The First Portuguese India Company (1628-1633)”. The Economic History Review, v.30, n.2 (May 1977), p.242-58; SUBRAHMANYAM, Sanjay. O império asiático português, 1500-1700. Uma história política e económica. Lisboa: Difel, 1995, p.225-31; COSTA, Leonor Freire. O transporte no Atlântico e a Companhia Geral do Comércio do Brasil (1580-1663). Lisboa: CNCDP, 2002, 2v.; Bibliothèque Nationale de France, Manuscrits Occidentaux, Fonds Portugais, Portugais 25, f.150-150v (proposta de Manuel Rodrigues de Andrade e Pascoal Pereira Jansen) e 67-68 (parecer de Bartolomeu Galvão da Rocha).

${ }^{18}$ IAN/TT, Conselho Ultramarino, Livro 1 (Decretos), 191v (1682); AHU, cód. 296 (Contratos reais), f.42v-44v (1682); AHU, cód. 268 (Cartas para o Maranhão), f.32-32v (1682). Cartas notificando a celebração do contrato foram enviadas às Câmaras de Belém e São 
Luís, ao governador, e para o bispo do Maranhão. AMARAL, José Ribeiro do, op. cit., p.34; CARREIRA, António, op. cit., p.18; AHU, cód. 296 (Contratos Reais), f.15v-17 (1676). A primeira companhia da região fora a da Costa da Guiné ou do Porto de Palmida, estabelecida em 1664. Ver: CARREIRA, António, op. cit., p.16. O contrato da Companhia do Maranhão reproduzido por António Carreira é um extrato, ver ibidem, p.298-304.

${ }^{19}$ BARRY, Boubcar. "La Sénégambie du XVIe au XVIIIe siècle: évolution des Wolof, des Seereer et des Tukuloor”. In: OGOT, B. A. Histoire générale de l'Afrique. Paris: Présence Africaine/Edicef/Unesco, 1998, p.198-205; MARK, Peter. “The evolution of 'Portuguese' identity: Luso-Africans on the Upper Guinea Coast from the sixteenth to the early nineteenth century". Cambridge: Journal of African History, v.40, 1999, p.183-6; CAVALCANTI, Nireu Olveira. "O comércio de escravos no Rio setecentista”. In: FLORENTINO, Manolo (Org.) Tráfico, cativeiro e liberdade. Rio de Janeiro, séculos XVII-XIX. Rio de Janeiro: Civilização Brasileira, 2005, p.18-9; AHU, Maranhão (Avulsos), cx. 6, doc. 708 (1685); As consultas da Junta, de 1686, estão em: AHU, Maranhão (Avulsos), cx. 7, doc. 770 (1687); CARDOSO, Alírio Carvalho, op. cit., p.44-62; ver: "Petição de Symão Estacio da Silveira”. Madrid, 15 de junho de 1626. Revista do IHGB, tomo 83 (1919), p.91-9; "Derrota del Rio de las Amazonas dada por el Capitan Manuel de Sosa Dessa al Señor Virrey”. [1615]. Annaes da Bibliotheca Nacional do Rio de Janeiro, v.26, 1904, p.277-9; "Requerimento de Martim Soares Moreno para que o Ceará continue a ser do governo do Brazil e não de Maranhão”. [1625]. In: Documentos para a historia do Brasil especialmente a do Ceará. 1608-1625. Editados por Guilherme de Studart [Barão de Studart]. Fortaleza: Typ. Studart, 1904, v.I, p.309.

${ }^{20}$ Sobre a revolta de Beckman, ver: LISBOA, João Francisco. Crônica do Brasil colonial: apontamentos para a história do Maranhão [1853-58]. Petrópolis: Vozes; Brasília: INL, 1976, p.425-90; AZEVEDO, João Lúcio de, op. cit., p.101-21; COUTINHO, Milson. A revolta de Bequimão. 2.ed. São Luís: Instituto Geia, 2004; MACNICOLL, Murray Graeme. "Seventeenth-Century Maranhão: Beckman's revolt”, Estudos ibero-americanos, v.4, n.1 (jul. 1978), p.129-40; LIBERMAN, Maria. O levante do Maranhão. Judeu Cabeça de Motim: Manoel Beckman. São Paulo: Centro de Estudos Judaicos/USP, 1983.

${ }^{21}$ AHU, Maranhão (Avulsos), cx. 6, doc. 721 (1685); IAN/TT, Coleção São Vicente, v.23, f.155v-156v ([1684]); AHU, Maranhão (Avulsos), cx. 6, doc. 726 (1685); AHU, Pará (Avulsos), cx. 3, doc. 252 (1685); LGM, p.97-101 (1688).

${ }^{22}$ REIS, Arthur Cezar Ferreira. "O negro na empresa colonial dos portugueses na Amazônia”, p.350. Sobre o número e a procedência dos escravos africanos para o Estado do Maranhão seiscentista, ver: PEREIRA, Manuel Nunes. "Negros escravos na Amazônia. Na Ilha Grande do Marajó. Um escorço histórico-geográfico”. In: CONGRESSO BRASILEIRO DE GEOGRAFIA, X, Anais... Rio de Janeiro: Conselho Nacional de Geografia, 1952, v.3, p.1619 e 171-3; SILVA, Anaíza Vergolino e. Alguns elementos para o estudo do negro na Amazônia. Belém: Museu Paraense "Emílio Goeldi”, 1968; MEIRELES, Mário Martins. Os negros no Maranhão. São Luís: UFMA, 1983, p.31-40; SALLES, Vicente, op. cit., p.47-59. Para uma crítica à abordagem "culturalista” sobre a questão da origem dos escravos, ver: SOARES, 
Mariza de Carvalho. "Mina, Angola e Guiné: nomes d'África no Rio de Janeiro setecentista”. Tempo, v.3, n.6 (dez. 1998), p.73-93. SOARES, Mariza de Carvalho. Devotos da cor: identidade étnica, religiosidade e escravidão no Rio de Janeiro, século 18. Rio de Janeiro: Civilização Brasileira, 2000, p.60; CARREIRA, António, op. cit., v.I, p.43. Sobre as transformações e o declínio do tráfico negreiro em Angola, ver: FERREIRA, Roquinaldo Amaral, op. cit., p.16-69.

${ }^{23}$ IAN/TT, Conselho Ultramarino, Decretos, livro 1, f.59-59v (1680), AHU, Maranhão (Avulsos), cx. 6, doc. 649 (1680); IAN/TT, Conselho Ultramarino, Decretos, livro 1, f.62v (1680); AHU, cód. 296 (Contratos reais), f.39-41 (1680), AHU, cód. 274 (Consultas do Maranhão), f.24 (1681), AHU, cód. 49 (Consulta de partes), f.50-50v (1683); AHU, Maranhão (Avulsos), cx. 7, doc. 778 (1687); AHU, cód. 296 (Contratos reais), f.42v-44v (1682), AHU, Maranhão (Avulsos), cx. 7, doc. 763 (1686); AHU, cód. 296 (Contratos reais), f.7980 (1692); AHU, Maranhão (Avulsos), cx. 8, doc. 858 (1693), AHU, cód. 296 (Contratos reais), f.95-96 (1693); LGM, p.153 (1695); AHU, cód. 268 (Cartas para o Maranhão), f.125 (1697); AHU, Maranhão (Avulsos), cx. 9, doc. 965 ([1698]), AHU, cód. 296 (Contratos reais), f.119v-120v (1698), AHU, cód. 274 (Consultas do Maranhão), f.124v (1698), AHU, Maranhão (Avulsos), cx. 9, doc. 974 (1699); AHU, cód. 274 (Consultas do Maranhão), f.159v (1702); AHU, cód. 268 (Cartas para o Maranhão), f.202v (1705), AHU, Maranhão (Avulsos), cx. 10, doc. 1077 (1705).

${ }^{24}$ AHU, cód. 1269 (Mapa dos contratos reais), f.12v; BETTENDORF, João Felipe, op. cit., p.296; AHU, Maranhão (Avulsos), cx. 5, doc. 563 (1671). Segundo o padre Bettendorf as naus trouxeram 900 escravos. BETTENDORF, João Felipe, op. cit., p.292; AHU, cód. 268 (Cartas para o Maranhão), f.2-2v (1673); AHU, Pará (Avulsos), cx. 3, doc. 258 (1686); As referências aos três navios do estanco de 1682 estão em: MORAES, Francisco Teixeira de. "Relação historica e politica dos tumultos que succederam na cidade de S. Luiz do Maranhão" [1692]. Revista do Instituto Histórico e Geográfico Brasileiro, tomo 40 (1877), p.353; BERREDO, Annaes historicos do Estado do Maranhaõ. Fac-símile da primeira ediçao, 1749. Iquitos: Ceta/Abya-Yala/IIAP, 1989, p.608-9 (\$ 1307), e AHU, Pará (Avulsos), cx. 3, doc. 258 (1686); AHU, cód. 274 (Consultas do Maranhão), f.74v (1691); AHU, Maranhão (Avulsos), cx. 8, doc. 869 (1693), AHU, Maranhão (Avulsos), cx. 9, doc. 931 (1697); AHU, cód. 94 (Provisões), f.446v-447 (1698), AHU, cód. 95 (Provisões), f.30-30v (1695), AHU, Maranhão (Avulsos), cx. 9, doc. 974 (1699), AHU, Maranhão (Avulsos), cx. 10, doc. 1040 (1700); LGM, p.225-6, 227, 228 (1702) e 240 (1703), AHU, cód. 268 (Cartas para o Maranhão), f.177v-178 (1702); AHU, cód. 268 (Cartas para o Maranhão), f.202v (1705), AHU, Maranhão (Avulsos), cx. 10, doc. 1077 (1705), LGM, p.264 (1705).

${ }^{25}$ AHU, Maranhão (Avulsos), cx. 5, doc. 547 (1670); AHU, cód. 93 (Provisões), f.188v (1678); AHU, cód. 93 (Provisões), f.209-209v (1679); AHU, cód. 93 (Provisões), f.428v (1687); LGM, p.153 (1695); AHU, Maranhão (Avulsos), cx. 9, doc. 931 (1697).

${ }^{26}$ AHU, cód. 93 (Provisões), f.258; LGM, p.153 (1695); AHU, Maranhão (Avulsos), cx. 10, doc. 1040 (1700); AHU, cód. 268 (Cartas para o Maranhão), f.200v. 
${ }^{27}$ SCHWARTZ, Stuart. "Indian labor and New World plantations: European demands and Indian responses in northeastern Brazil". The American Historical Review, Washington (DC), v.83, n.1 (Feb. 1978), p.43-79; CAVALCANTI, Nireu Olveira, op. cit., p.18; HANSON, Carl. Economia e sociedade no Portugal barroco. Lisboa: Quixote, 1986, p.243-56; ALENCASTRO, Luiz Felipe de. O trato dos viventes. Formação do Brasil no Atlântico sul. São Paulo: Companhia das Letras, 2000, p.138-41; "Parecer sobre se augmentar o Estado do Maranham fazendo-se assento para negros de Cabo Verde. Feyto por Joam de Moura" [1692-93]. BNP, Reservados, COD 1570, p.325; BETTENDORF, João Felipe, op. cit., p.2912; AHU, Maranhão (Avulsos), cx. 8, doc. 869. Sobre a lavoura de anil na América portuguesa (século XVIII), ver: ALDEN, Dauril. “The growth and decline of Indigo production in colonial Brazil: a study in comparative economic history". The Journal of Economic History, v.XXV, n.1 (Mar. 1965), p.35-60. Sobre o anil no Estado do Maranhão, ver: CHAMBOUlEYRON, Rafael. Portuguese colonization of the Amazon region, 1640-1706. Tese de doutorado (História), University of Cambridge, 2005, p.200-4.

${ }^{28}$ PAXECO, Fran. O Maranhão. Subsídios históricos e corográficos. São Luís: Typogravura Teixeira, 1912, p.132; "Papel sobre o governo do Estado do Maranhaõ e sua extençaõ. Por Manoel Da Vide Soutomayor. Anno de 1663 e restituiçaõ dos Padres da Comp.”. BA, cód. 54-XIII-4, no 42a; MOURA, João de. "Collonia portugueza que conthem tres tratados: no primeyro se descreve o estado do Maranhão e forma de seu augmento... Por João de Moura, cavalleiro professo da Ordem de Christo. Anno 1684". BNP, Reservados, COD 585, f.13v; ARANHA, Manuel Guedes. "Papel político sobre o Estado do Maranhão" [c.1685]. Revista do IHGB, tomo 46 (1883), $1^{\text {a }}$ parte, p.4, 7 e 12; FERREIRA, João de Sousa. "America abreviada. Suas noticias e de seus naturaes, e em particular do Maranhão, titulos, contendas e instrucções a sua conservação e augmento mui uteis" [1693]. Revista do IHGB, tomo 57 (1894), $1^{\text {a }}$ parte, p.33, 37 e 43.

${ }^{29}$ AMARAL, José Ribeiro. “Qual será a população atual de São Luís?” [1912]. In: O Maranhão histórico. São Luís: Instituto Geia, s.d., p.61-63; MOTT, Luiz. "A inquisição no Maranhão”. São Paulo: Revista Brasileira de História, v.14, n.28, 1994, p.51; IAN/TT, Inquisição de Lisboa, Cadernos do Promotor, livro 263, f.274 (1693); IAN/TT, Inquisição de Lisboa, Cadernos do Promotor, livro 263, f.278v (1693); IAN/TT, Inquisição de Lisboa, Cadernos do Promotor, livro 263, f.278 (1692); IAN/TT, Inquisição de Lisboa, Correspondência recebida de comissários, livro 922, f.710-712v (1691); IAN/TT, Inquisição de Lisboa, Correspondência recebida de comissários, livro 922, f.779-786 (1692); "Rol dos cazamentos feytos nesta Igreja de Sam Francisco Xavier”. [1670-1724]. BNP, Reservados, Coleção Pombalina, no 4, f.18 e 20; "[Rol dos batismos feitos na igreja de São Francisco Xavier]". [1670-1737]. BNP, Reservados, Coleção Pombalina, no 4, f.39v e 41v; BETTENDORF, João Felipe, op. cit., p.37-8; AHU, Maranhão (Avulsos), cx. 10, doc. 1045 (1701); LGM, p.208-9 (1701); AHU, códice 268 (Cartas para o Maranhão), f.174v-175 (1702); LGM, p.255 (1703). ${ }^{30}$ Além das obras citadas ao longo do texto, sobre a presença africana no Maranhão e no Pará no período colonial, principalmente durante o século XVIII, ver: GOMES, Flávio dos 
Santos. "Fronteiras e mocambos: o protesto negro na Guiana brasileira". In: GOMES, Flávio dos Santos (Org.) Nas terras do Cabo do Norte: fronteiras, colonização e escravidão na Guiana brasileira (séculos XVIII-XIX), p.225-318; GOMES, Flávio dos Santos. "A 'Safe Haven': runaway slaves, mocambos, and borders in Colonial Amazonia, Brazil". Hispanic American Historical Review, Durham, v.82, n.3, 2002, p.469-98; KELLY-NORMAND, Arlene Marie. "Africanos na Amazônia cem anos antes da abolição". Cadernos do CFCH, Belém, v.18 (out.-dez. 1988), p.1-21; MACLACHLAN, Colin. "Slavery, ideology, and institutional change: the impact of the Enlightenment on slavery in late eighteenth-century Maranhão". Journal of Latin American Studies, Cambridge, v.11, issue 1 (May 1979), p.1-17; NOGUEIRA, Shirley Maria Silva \& GOMES, Flávio dos Santos. "Outras paisagens coloniais: notas sobre desertores militares na Amazônia setecentista”. In: GOMES, Flávio dos Santos (Org.) Nas terras do Cabo do Norte, p.196-224; QUEIROZ, Jonas Marçal de \& GOMES, Flávio dos Santos. "Em outras margens: escravidão africana, fronteiras e etnicidade na Amazônia". In: PRIORE, Mary del \& GOMES, Flávio dos Santos (Orgs.) Os senhores dos rios. Amazônia, margens e histórias. Rio de Janeiro: Elsevier, 2003, p.141-63; SALLES, Vincente. O negro na formação da sociedade paraense. Belém: Paka-Tatu, 2004. 